\title{
Water quality in New Zealand's planted forests: a review
}

Brenda R Baillie ${ }^{1 *}$ and Daniel G Neary ${ }^{2}$

\begin{abstract}
This paper reviewed the key physical, chemical and biological water quality attributes of surface waters in New Zealand's planted forests. The purpose was to: a) assess the changes in water quality throughout the planted forestry cycle from afforestation through to harvesting; b) compare water quality from planted forests with other land uses in New Zealand; and c) identify knowledge gaps and opportunities for future research. Afforestation of pasture land significantly improved a wide range of water quality attributes such as stream temperature, nutrient and sediment concentrations and microbial contamination within 4-6 years of planting. Water quality in mid-rotation to mature forests, a large proportion of the forestry cycle, was highly variable but characterised by cool water temperatures, low concentrations of sediment and nutrients, with aquatic invertebrate communities indicative of high water quality. Impacts of timber harvesting on water quality attributes were greatest when clear-cut harvesting up to the stream edge. Harvest impacts were mediated by the retention of intact riparian buffers and to a lesser extent by retention of moderate quantities of logging slash across small stream channels. Temporal and spatial factors influenced the magnitude of response to harvesting activities and duration of the recovery period. Land-use comparisons generally showed improving water quality from pasture to planted forest to indigenous forest. Continued research to identify management systems that mitigate impacts on water quality, particularly during harvesting, remains a priority. Consistent approaches to water quality monitoring will improve the ability to report on water quality in planted forests. Future water quality research in New Zealand's planted forests needs to encompass emerging contaminants of national and international concern such as pesticides and pharmaceuticals. As New Zealand moves toward increasing productivity from planted forests, use of potential interventions such as intensified herbicide and fertiliser use, will need to be within sustainable freshwater limits. A future challenge is to quantify the economic value of freshwater ecosystems services provided by New Zealand's planted forests. This review showed that with continued prudent stewardship and ongoing improvements in management practices, particularly during harvesting, New Zealand's planted forests can provide a sustainable source of well-maintained and high quality water resources.
\end{abstract}

Keywords: New Zealand; Planted forest; Water quality; Land use

\section{Introduction}

\section{Water quality in forests}

Clean fresh water is essential for terrestrial and aquatic life, and "water quality" is a term used to describe the physical, chemical, and biological characteristics of water (Carr and Neary 2008). There are a number of key drivers influencing water quality such as geological weathering; hydrologic and geomorphic processes; climatic conditions; and physical, chemical and biological processes in terrestrial and aquatic environments. The

\footnotetext{
* Correspondence: brenda.baillie@scionresearch.com

'SCION, Private Bag 3020, Rotorua 3046, New Zealand

Full list of author information is available at the end of the article
}

combination and interaction of these processes produces extremely complex and dynamic systems that vary considerably both temporally and spatially within landscapes. Thus, water quality at a given time and at a given point in a catchment is determined by a range of current and historical influences of natural and anthropogenic origin and provides an important indicator of aquatic ecosystem health (Carr and Neary 2008; Feller 2005; Gleick 1993; Roux et al. 1993).

Forests have a strong influence on catchment hydrology and water quality. Interception and evapotranspiration processes in forests reduce the amount of precipitation reaching the forest floor. The physical, biological and

\section{实 Springer}

(C) 2015 Baillie and Neary; licensee Springer. This is an Open Access article distributed under the terms of the Creative Commons Attribution License (http://creativecommons.org/licenses/by/4.0), which permits unrestricted use, distribution, and reproduction in any medium, provided the original work is properly credited. 
chemical characteristics of forest soils facilitate water filtration, contaminant removal, and nutrient recycling. Subsurface flow provides the primary pathway for transport of water to streams, subsequently reducing overland flow and associated erosion and soil loss. In addition, forests moderate climatic extremes, influencing the quantity, timing, thermal regime and water quality characteristics of stream water (Neary et al. 2009; O'Loughlin 1994). As a result, forests generally yield higher water quality than other land uses such as agriculture and urban development (Cooper and Thomsen 1988; Foley et al. 2005; Quinn et al. 1997). They are renowned for producing sustainable supplies of high-quality water and vital sources of drinking water around the world (Dissmeyer 2000; Dudley and Stolton 2003; Neary et al. 2011).

Mature planted forests often have water quality attributes similar to those in undisturbed indigenous forests, but water quality can vary considerably throughout the forest cycle depending on the management activities and the level of disturbance they generate (Harding and Winterbourn 1995; Hartman 2004; Neary et al. 2011; Pike et al. 2010). Furthermore, underlying natural processes and legacies from historical land-use practices can sometimes have a greater influence on some aspects of water quality in planted forests than the current land use itself (Davis 2014; Parkyn et al. 2006; Quinn et al. 1997).

\section{New Zealand's planted forests}

New Zealand has a land area of $268,021 \mathrm{~km}^{2}$ with a latitude range of over $12^{\circ}$ (from $34^{\circ} 23^{\prime} 47^{\prime \prime} \mathrm{S}$ to $46^{\circ} 40^{\prime}$ $32^{\prime \prime}$ S). Climate varies from subtropical to subantarctic but is mostly cool to temperate (Manatū Taonga Ministry for Culture and Heritage 2014). Planted forests are distributed throughout the two largest islands of New Zealand (Figure 1) covering 1.7 million ha (6\% of New Zealand's land area), with $90 \%$ of the area in Pinus radiata D.Don (Forest Owners Association \& Ministry for Primary Industries 2013). Around $20 \%$ of the planted forest estate is in steep $\left(>20^{\circ}\right)$ hill country which is highly erodible and susceptible to extreme weather events (Dunningham et al. 2012). Eight major soil orders underlie $96.5 \%$ of the planted forest estate, the main ones being Brown, Pumice and Recent soils (Watt et al. 2010). Based on the New Zealand Land Cover Database v4.0 (Landcare Research 2014) and the River Environment Classification (Snelder \& Biggs 2002), there are an estimated 24,220 $\mathrm{kms}$ of streams in New Zealand's planted forests.

\section{Scope and organisation of the review}

This paper reviewed publically available peer-reviewed literature on water quality in New Zealand's planted forests. Most of the publications are research papers in small-scale catchments. The review provides an updated and more in-depth review encompassing the broader physical, chemical and biological definition of water quality than previous reviews of water quality in New Zealand's planted forests undertaken 10-20 years previously (Fahey et al. 2004; Maclaren 1996; O'Loughlin 1994). The review focuses on the water quality of surface freshwaters (primarily streams) excluding groundwater and water quantity (see Davie and Fahey 2005). It covers the key attributes relating to the physical (i.e. temperature, dissolved oxygen, sediment, electrical conductivity), chemical (i.e. nitrogen $(\mathrm{N})$, and phosphorus $(\mathrm{P})$ ), and biological (i.e. periphyton, micro-organisms, invertebrates) aspects of water quality in New Zealand's planted forests. Currently, the use of freshwater fish as an indicator of water quality in New Zealand's planted forest streams is limited, so this attribute has not been included in this review. For the purposes of this review, light levels are included under the physical attributes of water quality.

The first section reviews the effect of planted forests on water quality over the time period of a forestry management cycle, from afforestation of agricultural land (six publications), through the growth cycle to forest maturity (40 publications) followed by harvesting and subsequent re-establishment of the next crop (23 publications) to determine the effects of forest management activities on water quality. The second section compares the effects of planted forests on water quality relative to other land uses (27 publications), with a final section identifying knowledge gaps for future research.

\section{Review}

Water quality in New Zealand's planted forests Afforestation phase: planting to forest canopy closure

Planting of agricultural land into tree crops can lead to improvements in various attributes of water quality within four to six years, mainly through changes in riparian characteristics, (particularly in smaller sized streams) and reducing inputs of agricultural contaminants.

Physical attributes Afforestation of a 95 ha catchment in Waikato hill country significantly reduced stream temperatures within six years of planting to temperatures below that considered stressful to sensitive aquatic invertebrates and were predicted to achieve a forested thermal regime within 10 years of planting (Quinn et al. 2009; Quinn et al. 1994). The Blaschke et al. (2008) review of a range of studies across New Zealand found that afforestation was particularly effective in reducing average annual sediment yields in small catchments. Reductions ranged from 50 to greater than $80 \%$ although the variability was strongly influenced by underlying geology and rainfall. 


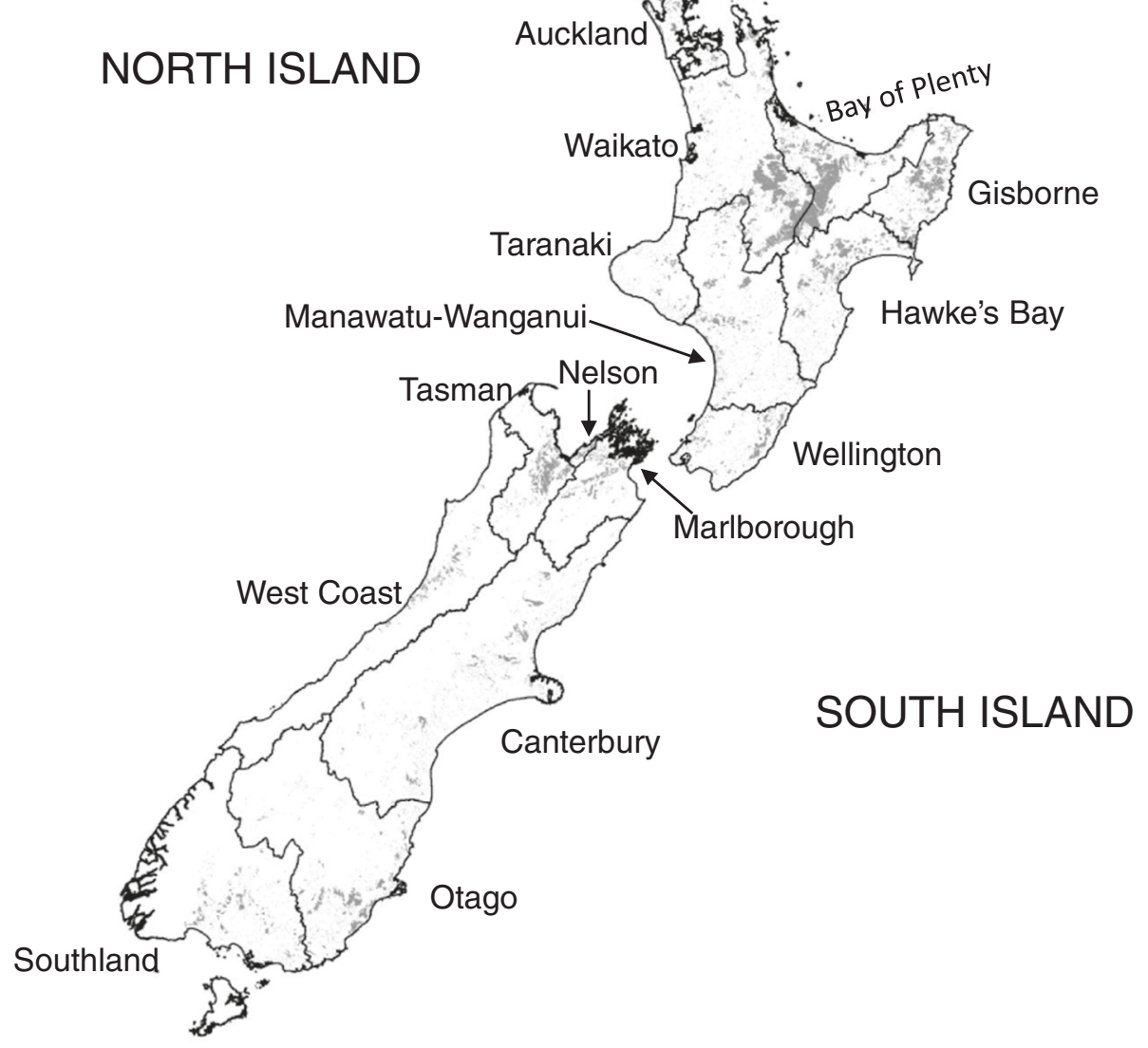

Figure 1 Map of New Zealand showing the regional boundaries (dark line) and distribution of New Zealand's planted forests (shaded areas). Map provided by the Geo-spatial analyst team, Scion, Rotorua, New Zealand.

Nutrients The nutrient content of stream water can change substantially after afforestation. For example, total phosphorus (TP) and dissolved reactive phosphorus (DRP) concentrations declined within 4-5 years of planting a small (34 ha) pasture catchment in the Central North Island in P. radiata in comparison with an adjacent pasture stream (Cooper et al. 1987). Nitrate-nitrogen $\left(\mathrm{NO}_{3}-\mathrm{N}\right)$ response in the afforested catchment varied over time, but long-term records showed a decline in $\mathrm{NO}_{3}-\mathrm{N}$ within 5 years of planting (Davis 2014).

Biological attributes Periphyton biomass declined significantly within six years of afforestation of a 95-ha hill country catchment in the Waikato region of the North Island (Quinn et al. 2009). Macroinvertebrate community composition changed within six years of planting. Increases were observed in the environmentally sensitive taxa (Ephemeroptera (mayflies), Plecoptera (stoneflies) and Trichoptera (caddisflies) (EPT)), reflecting a shift in community structure toward one associated with indigenous forest streams (Quinn et al. 2009). In the same region, Donnison et al. (2004) found that microbial contamination by Escherichia coli declined by a factor of 10 (to a median concentration of 41 E. coli $100 \mathrm{~mL}^{-1}$ ) over the two years following the afforestation of three small pasture sub-catchments. Some of this effect was attributed to concurrent stock exclusion and pest control. Microbial contamination was also low (median concentration 83 E. coli $100 \mathrm{~mL}^{-1}$ ) in four small subcatchments seven years after conversion to Pinus radiata.

\section{Mature forest phase: canopy closure to forest maturity}

Canopy closure occurs at around six to eight years of age in $P$. radiata stands depending on tree stocking (Cooper et al. 1987; Eyles and Fahey 2006). Forest 
maturity and subsequent harvest occurs between 25 to 30 years of age. In general, water quality in mature planted forest streams is of a high quality.

Physical attributes Streams in mature plantation forest streams are highly shaded (mean or median light levels at the water level ranged from 1.3 to $12.1 \%$ of an open reference site). Shade levels were strongly influenced by riparian vegetation condition and channel width (Baillie et al. 2005; Boothroyd et al. 2004; Davies-Colley and Quinn 1998; Thompson et al. 2009).

The variation in methods used to collect stream temperature data and the wide range of temperature attributes reported in the literature, made it challenging to compare across studies (Table 1). Overall, water temperatures in mature forest streams were cool $\left(<15^{\circ} \mathrm{C}\right.$ in most studies) with temperature variability influenced by hydrology and latitude. Water temperatures tended to be higher in the northern regions of New Zealand and were generally cooler in the more hydrologically stable, spring-fed streams in the Central North Island and southern regions of New Zealand (Table 1). These stream temperatures were below those considered stressful for more sensitive aquatic invertebrate and fish species (Olsen et al. 2012; Quinn et al. 1994; Richardson et al. 1994).

Low light levels in mature planted forest streams limit primary productivity from aquatic plants (i.e. macrophytes and periphyton) (Boothroyd et al. 2004; Thompson et al. 2009). Consequently, temperature is the main factor influencing dissolved oxygen (DO) concentrations (higher concentrations of DO occur at lower temperatures). Dissolved oxygen is an important indicator of water quality and essential to the life supporting capacity of aquatic environments. Hence a minimum concentration of $80 \%$ of saturated concentration is required by the Resource Management Act (1991). In most studies, concentrations of DO in mature forests were above this concentration (Collier and Bowman 2003; Collier and Halliday 2000; Matheson et al. 2011; Pruden et al. 1990). An exception of $72 \%$ was recorded in a forested Northland stream by Baillie et al. (2005), which the authors attributed to the warmer thermal regimes in this region.

Estimated sediment yields in mature planted forests across New Zealand ranged from 1.7 to $46 \mathrm{t} \mathrm{km}^{-2} \mathrm{yr}^{-1}$ (Basher et al. 2011; Dons 1987; Fahey and Marden 2006; Hicks 1990). The majority of these sites are in steep hill country. Geology influenced these results with lower yields generated from volcanic soils, Moutere Gravel, and schist. Highest sediment yields were generated in terrains with greywacke parent material and Separation Point Granite. Turbidity and suspended sediment (SS) concentrations in mature planted forests were low across all geological groups (turbidity $\leq 2$ NTU's; SS concentrations $<3 \mathrm{~g} \mathrm{~m}^{-3}$ ) except where gullying occurred in soft-rock geologies (turbidity 0.8 to 100 NTUs; SS concentrations $<1.2$ to $100 \mathrm{~g} \mathrm{~m}^{-3}$ ). Elevated turbidity and suspended solid concentrations and low water clarity were also recorded in a first rotation planted forest in the Waikato hill country, and were attributed to the remobilisation of channel bank material accumulated under a previous pasture land-use regime (Quinn et al. 1997).

Nutrients Concentrations for a range of $\mathrm{N}$ and $\mathrm{P}$ attributes measured in mature planted forest streams varied by at least an order of magnitude (Figure 2) but in most studies, concentrations were low. The reasons for the higher levels of nutrients recorded in some studies were not always obvious, but underlying lithologies and associated soils, previous land-use practices and localised inputs of atmospheric $\mathrm{N}$ are possible contributing factors (Davis 2014; Macaskill et al. 1997; Parkyn et al. 2006).

Biological attributes Similar to physico-chemical attributes, biological indicators of water quality in midrotation to mature planted forest stands also varied considerably. Concentrations of $E$. coli in mid rotation and mature planted stands were generally below $150 \mathrm{E}$. coli $100 \mathrm{~mL}^{-1}$ (Fahey and Stansfield 2006; Parkyn et al. 2006; Young et al. 2005). The most likely source is faecal contamination originating from birds and feral animals such as possums, pigs, and deer.

The shady, cool, low nutrient and sediment stream environments in mature planted forests supported aquatic invertebrate communities containing the more sensitive EPT taxa (Table 2). Ephemeroptera taxa, in particular, dominated many of these invertebrate communities (Baillie et al. 2005; Collier and Halliday 2000; Death et al. 2003; Harding and Winterbourn 1995; Quinn et al. 1997; Shearer and Young 2011), although Diptera (mainly Chironomidae) dominated invertebrate communities in several South Island streams (Friberg et al. 1997; Shearer and Young 2011). Lower invertebrate densities and \%EPT were usually associated with suboptimal sandy, mobile substrates or high levels of fine sediment (Baillie et al. 2005, Collier and Halliday 2000). The macroinvertebrate community index (MCI) and quantitative MCI (QMCI) are well-established biological metrics used as indicators of water quality in New Zealand (Boothroyd and Stark 2000). Most of the MCI and QMCI scores for streams in mature planted forests gave a ranking of 'clean water' or, 'mild pollution' (Boothroyd and Stark 2000) (Table 2). A QMCI score indicative of 'probable moderate pollution' was recording in mature planted forest streams in the Moutere Gravels of the Nelson region (Shearer and Young 2011). This result was possibly influenced by an intermittent flow regime. 
Table 1 Stream temperature characteristics in mature planted forest and harvested streams

\begin{tabular}{|c|c|c|c|c|c|c|c|}
\hline Region & No. of sites & $\begin{array}{l}\text { Riparian } \\
\text { buffer }\end{array}$ & Monitoring period & Temperature $(T)$ variable & Mature forest $\left({ }^{\circ} \mathrm{C}\right)$ & After harvest $\left({ }^{\circ} \mathrm{C}\right)$ & Change after harvest \\
\hline \multirow[t]{4}{*}{ Northland ${ }^{1}$} & \multirow[t]{4}{*}{4} & \multirow[t]{4}{*}{ No } & \multirow[t]{4}{*}{$C: 3$ years } & Mean annual $\mathrm{T}$ & $12.7-13.9$ & $14.5 \& 15.1$ & \multirow{4}{*}{$\begin{array}{l}\text { Significant increase in } \\
\text { mean annual \& maximum monthly } \\
\text { temperatures c.f. control site }\end{array}$} \\
\hline & & & & Mean monthly maximum T & 14.9 & $20.2 \& 18.6$ & \\
\hline & & & & Daily maximum $T$ & & $26.3 \& 23.3$ & \\
\hline & & & & Mean diurnal range (Jan-Feb) & $1.4-2.5$ & $7.1 \& 4.1$ & \\
\hline \multirow[t]{2}{*}{ Waikato $^{2}$} & \multirow[t]{2}{*}{5} & \multirow[t]{2}{*}{ NA } & \multirow[t]{2}{*}{ C: Nov. - Dec. } & Mean T & 13 & & \multirow[t]{2}{*}{ NA } \\
\hline & & & & Maximum T & 15.5 & & \\
\hline \multirow[t]{3}{*}{ Waikato $^{3}$} & 1-mature & Yes & \multirow[t]{3}{*}{ C: Oct. - Jan. } & Mean $T$, max. $T$, diurnal range & $16,21.2,3-4$ & & \multirow{3}{*}{$\begin{array}{l}\text { Water temperatures significantly } \\
\text { higher at the harvest sites } \\
\text { c.f. control sites }\end{array}$} \\
\hline & 1-harvest & No & & Mean T, max. T, diurnal range & & $18.7,30.2,10-12$ & \\
\hline & 1-harvest & Yes & & Mean $T$, max. T, diurnal range & & $16.6,23.9,3-4$ & \\
\hline \multirow[t]{2}{*}{ Waikato $^{4}$} & \multirow[t]{2}{*}{12} & & \multirow{2}{*}{$\begin{array}{l}\text { C: Dec. - Jan. } \\
\text { for } 13 \text { years }\end{array}$} & Summer daily mean $T$ & 16.7 & & T increase $2-3.8^{\circ} \mathrm{C}$ c.f. control sites \\
\hline & & & & Summer daily max. $T$ & 18.5 & & T increase $4-7.3^{\circ} \mathrm{C}$ c.f. control sites \\
\hline Bay of Plenty ${ }^{5}$ & 3 & NA & $\begin{array}{l}\text { C: spring \& autumn } \\
\text { for } 2 \text { years }\end{array}$ & Mean T & $9.9-14.6$ & & NA \\
\hline $\mathrm{CNI}^{6}$ & 6 & No & S: early summer & T range & $12-13.5$ & $10.7^{*}-16.0$ & T $1-3^{\circ} \mathrm{C}$ higher in harvest c.f. shaded sites \\
\hline $\mathrm{CNI}^{7}$ & 8 & NA & S: early summer & Trange & 10.8-13.8 & & NA \\
\hline \multirow[t]{2}{*}{$\mathrm{CNI}^{8}$} & \multirow[t]{2}{*}{4} & \multirow[t]{2}{*}{ No } & S: over 2 years & Trange & \multirow[t]{2}{*}{$6.5-12.2$} & $7.8-13.8$ & \multirow{2}{*}{$\begin{array}{l}\text { Little variation between harvested } \\
\& \text { control sites }\end{array}$} \\
\hline & & & C: April - May & Mean $T$, diurnal range & & $9.8-10.3,0.5-2.0$ & \\
\hline Gisborne $^{9}$ & 4 & NA & C: February & Median T & 13.0-18.0 & & NA \\
\hline Hawke's Bay ${ }^{10}$ & 3 & No & S: $5.5-6.0$ years & Median T & 10.0-15.0 & pre- \& post-harvest & No significant change in $T$ after harvest \\
\hline \multirow[t]{3}{*}{ Nelson ${ }^{11}$} & 1 - mature & & \multirow[t]{3}{*}{ S: Jul., Oct., Mar., Jun. } & \multirow[t]{3}{*}{ Mean min. $T$, mean max. $T$} & & $4.0-9.4,6.8-13.1$ & \multirow{3}{*}{$\begin{array}{l}\mathrm{T} \text { up to } 6.5^{\circ} \mathrm{C} \text { higher in summer \& } \\
2.5^{\circ} \mathrm{C} \text { lower in winter c.f. control site }\end{array}$} \\
\hline & 2 - harvest & No & & & & $2.5-12.8,5.8-17.4$ & \\
\hline & 1 - harvest & Yes & & & & $6.1-10.6,7.1-12.1$ & \\
\hline \multirow[t]{2}{*}{ Nelson ${ }^{12}$} & \multirow[t]{2}{*}{2} & \multirow[t]{2}{*}{ NA } & \multirow[t]{2}{*}{ C: March - February } & Mean daily winter $T$, summer $T$ & $3-6,11.5-14$ & & \multirow[t]{2}{*}{ NA } \\
\hline & & & & Min. winter $\mathrm{T}$, max summer $\mathrm{T}$ & $0.5-3.0,15-18$ & & \\
\hline Canterbury $^{13}$ & 4 & NA & S: seasonal $(n=4)$ & Mean T & 7.3 & & NA \\
\hline Canterbury $^{14}$ & 4 & NA & Oct - Jan $(n=4)$ & Mean T & 9.5 & & NA \\
\hline Westland & 4 & NA & Oct - Jan $(n=4)$ & Mean $\mathrm{T}$ & 10.7 & & NA \\
\hline
\end{tabular}

Baillie et al. 2005' ${ }^{1}$; Quinn et al. $1997^{2}$; Boothroyd et al. 2004 ${ }^{3}$; Quinn and Wright-Stow 2008 Stansfield $2006^{10}$; Graynoth $1979^{11}$; Young et al. $2005^{12}$; Harding and Winterbourn $1995^{13}$; Friberg et al. $1997^{14}$,

Data taken from text and tables or estimated from graphs; Riparian buffer refers to the retention of an unharvested area of vegetation retained along the stream edge during harvesting.

$\mathrm{CNI}=$ central North Island.

$\mathrm{C}=$ continuous monitoring with a temperature data logger; $\mathrm{S}=$ spot temperatures taken during site visits.

*water temperature influenced by logging slash cover over stream channel. 


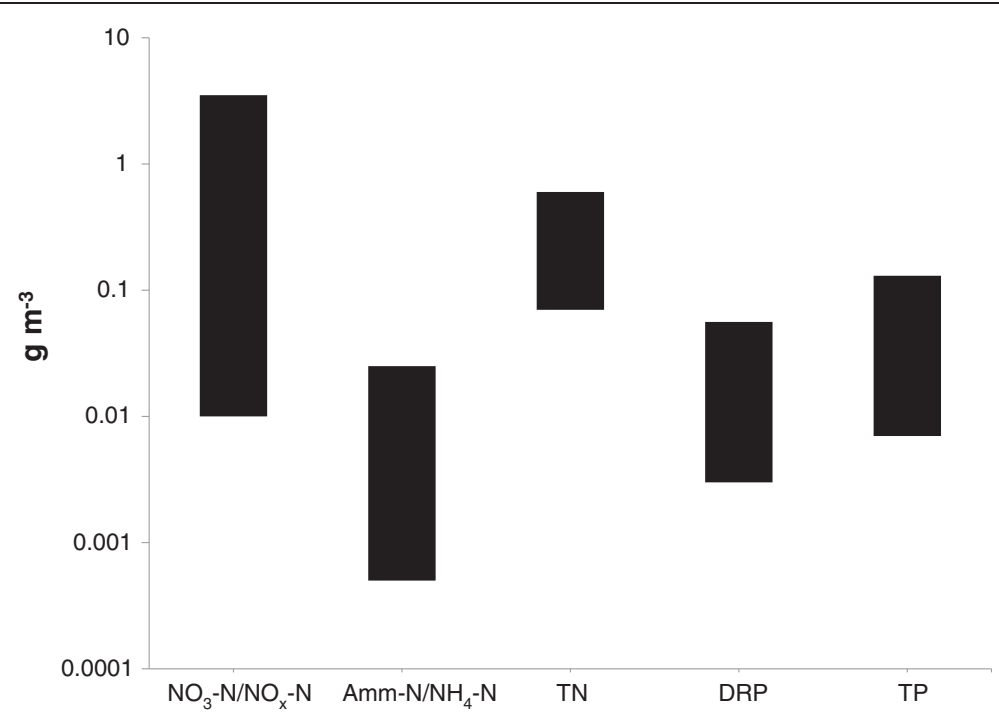

Figure 2 Range of nutrient concentrations in mature planted forest streams. $\mathrm{NO}_{x}-\mathrm{N}$ values have been aggregated with $\mathrm{NO}_{3}-\mathrm{N}$ as $\mathrm{NO}_{2}-\mathrm{N}$ is rapidly oxidised to $\mathrm{NO}_{3}-\mathrm{N}$ and typically comprises a small portion of oxidised-N. Similarly, Amm- $\mathrm{N}$ values have been aggregated with $\mathrm{NH}_{4}-\mathrm{N}$ values as $\mathrm{NH}_{3}-\mathrm{N}$ comprises a small component of Amm-N. Note the log scale on the y axis. Mean or median values derived from tables and text or estimated from figures in references (Collier and Bowman 2003; Cooper et al. 1987; Fahey and Stansfield 2006; Friberg et al. 1997; Harding and Winterbourn 1995; Macaskill et al. 1997; Matheson et al. 2011; Parkyn et al. 2006; Thompson et al. 2009; Thompson and Townsend 2004b; Townsend et al. 1997; Young et al. 2005). The wider range of $\mathrm{NO}_{3}-\mathrm{N} / \mathrm{NO}_{x}-\mathrm{N}$ concentrations compared with $\mathrm{TN}$ is influenced by studies that measured that measured concentrations of $\mathrm{NO}_{3}-\mathrm{N}$ at the high end of the range and either did not measure $\mathrm{TN}$ or measured $\mathrm{TN}$ at a lower sampling intensity than $\mathrm{NO}_{3}-\mathrm{N}$.

Effects of management activities Few published studies in New Zealand have evaluated the effects of forestry management activities (such as silvicultural treatments and pesticide application) on water quality during the growing phase of the forestry cycle and most studies are dated (i.e. Baillie et al. 2015; Collier and Winterbourn 1989; Jackson 1987; Neary and Leonard 1978). Some of these management activities have the potential to affect water quality e.g. Binkley et al. (1999) and Neary (2012).

The land preparation practice of V-blading in West Coast wetlands, where soil was mounded in rows to facilitate drainage and provide elevated sites for planting trees (Collier and Winterbourn 1989; Jackson 1987), elevated summer water temperatures in streams. The authors also recorded higher dissolved aluminium concentrations, and lower $\mathrm{pH}$ than streams draining indigenous forest catchments, lower aquatic invertebrate taxa richness in some very acidic streams and an increase in annual sediment yields.
Two studies (Leonard 1977; Neary and Leonard 1978) covering a range of New Zealand sites with varying geology, climate and hydrology found fertiliser application to trees on nutrient-deficient sites resulted in short-term increases in $\mathrm{N}$ and $\mathrm{P}$ in forest stream waters. The main pulse of $\mathrm{N}$ or $\mathrm{P}$ was detected either immediately (particularly when application was over the stream channel), just after fertiliser application, or during high flow events in the weeks or months immediately after fertiliser application. In general, nutrient levels returned to baseline levels within a few weeks or months of application. The authors did not consider the levels in stream water to be harmful as only a small portion of the total amount of fertiliser $(0.5 \%$ of total application) reached the streams.

Some conifers, including $P$. radiata, are susceptible to the Dothistroma needle blight (Bulman et al. 2004), a disease treated with aerial application of a copper $(\mathrm{Cu})$ fungicide spray. A preliminary study by Fish (1968) found very low levels of $\mathrm{Cu}$ (often below detection

Table 2 Range of key characteristics of aquatic invertebrate communities located in New Zealand streams bounded by mature planted forest ${ }^{1}$

\begin{tabular}{lllllll}
\hline \multicolumn{5}{l}{ Aquatic invertebrate attribute } & & \\
\cline { 2 - 6 } & Mean density $\left(\right.$ no. $\mathbf{m}^{-\mathbf{2}}$ ) & Taxa richness & No. EPT ${ }^{2}$ taxa & \% EPT & MCl $^{\mathbf{3}}$ & QMCl $^{\mathbf{4}}$ \\
\hline Range & $250-6540$ & $11-50$ & $13-65$ & $17-90$ & $100-130$ & $4.2-8.1$ \\
\hline
\end{tabular}

${ }^{1}$ Baillie et al. 2005; Baillie 2011; Collier and Bowman 2003; Collier and Halliday 2000; Death et al. 2003; Friberg and Winterbourn 1997; Harding and Winterbourn 1995; Parkyn et al. 2006; Quinn et al. 1997; Quinn et al. 2004; Shearer and Young 2011; Stark and Maxted 2007; Townsend et al. 1997.

${ }^{2}$ EPT: Ephemeroptera, Plecoptera, Trichoptera.

${ }^{3} \mathrm{MCl}$ : Macroinvertebrate Community Index.

${ }^{4} \mathrm{QMCl}$ : Quantitative Macroinvertebrate Community Index. 
limits) in stream water and small, but detectable, quantities of $\mathrm{Cu}$ in fine-particulate debris. Copper accumulation in aquatic invertebrates was variable, with highest concentrations occurring in the shells of a freshwater snail Potamopyrgus spp.

More recently, research on the aquatic fate of two commonly used herbicides in planted forests (hexazinone and terbuthylazine) showed that under operational conditions, short-term elevated concentrations in stream water occurred either on the day of herbicide application or during a rainfall event shortly after application. Thereafter concentrations were below drinking water standards and lethal concentrations for aquatic organisms and were rapidly diluted downstream, posing a low risk to the aquatic environment (Baillie et al. 2015).

\section{Harvesting and the post-harvest phase}

Not surprisingly, clear-cut harvesting can affect the physical, chemical and biological nature of freshwater environments (Aust and Blinn 2004; Baillie et al. 2005; Campbell and Doeg 1989; Pike et al. 2010). The time taken for these environments to recover to their preharvest state varies spatially and temporally across a wide range of water quality attributes.

Physical attributes One of the greatest changes associated with clear-cut harvesting to the stream edge is the increase in light levels (Allan and Castillo 2009). Postharvest light levels of 11 to $88 \%$ (compared with an open reference site) have been recorded in New Zealand streams in the first few years after harvest with marked increases in light occurring at stream widths of around 3.5 to $5 \mathrm{~m}$. Residual shade was provided by stream banks, logging slash, surrounding topography and any remaining vegetation. In some instances, residual logging slash across the stream channel resulted in light levels similar to those found in un-harvested streams ( $<5 \%$ of available light) (Davies-Colley and Quinn 1998; Thompson et al. 2009). Time frames for shade recovery were influenced by stream size and riparian vegetation regrowth (Baillie et al. 2005; Boothroyd et al. 2004; Davies-Colley and Quinn 1998; Thompson et al. 2009).

Temperature is an important factor influencing instream processes (Allan and Castillo 2009). Increased solar radiation following harvest to the stream edge often resulted in higher maximum stream temperatures (up to 25 to $30^{\circ} \mathrm{C}$ ) and diurnal temperature ranges of up to $12^{\circ} \mathrm{C}$ in the warmer northern latitudes of New Zealand and where the hydrology was dominated by surface and sub-surface flow (Baillie et al. 2005; Boothroyd et al. 2004; Graynoth 1979; Quinn and Wright-Stow 2008) (Table 1). Streams with cooler base flow temperatures, overhead logging slash cover and inputs from groundwater seepages, mediated the impact of reduced shade and increased solar radiation on water temperatures after harvest at some sites (Table 1) (Fahey and Stansfield 2006; Pruden et al. 1990). It is likely that, in some streams, temperatures after harvest are exceeding levels and duration periods considered stressful for some sensitive aquatic invertebrates and fish species $\left(\geq 23^{\circ} \mathrm{C}\right.$ for aquatic invertebrates and $\geq 28^{\circ} \mathrm{C}$ for indigenous fish) (Olsen et al. 2012; Quinn et al. 1994; Richardson et al. 1994).

Stream temperature recovery is closely linked to stream size, hydrology and riparian vegetation characteristics. Smaller streams are more thermally sensitive but riparian influence on shade is greater so thermal recovery is usually faster than for larger sized streams (Cristea and Janisch 2007; Moore et al. 2005). This was evident in Coromandel (Waikato region) streams where the time taken for thermal regimes to return to pre-harvest levels was six to eight years in small (2-4 $\mathrm{m}$ wide) streams, but predicted to take 12 to 16 years for medium sized $(6-12 \mathrm{~m})$ streams (Quinn and WrightStow 2008). Similar time frames for thermal recovery have been found in streams in the Pacific Northwest region of the USA (Moore et al. 2005).

The DO concentrations in stream water often decline in association with temperature increases after harvest, although microbial respiration (increased biological oxygen demand from processing residual in-stream organic matter from harvesting) and primary production can also affect DO (Allan and Castillo 2009). While minimal and short-term impacts on DO were observed in some streams, in others DO concentrations declined below the Resource Management Act threshold of $80 \%$ of saturated concentration (Resource Management Act 1991), with recovery to pre-harvest levels extending beyond one year (Baillie et al. 2005; Collier and Bowman 2003). Collier \& Bowman (2003) did note that high aeration rates contributed to the recovery of DO within $500 \mathrm{~m}$ downstream of one site.

Harvesting in steep hill country often increases sediment yields with most sediment reaching waterways via run-off from roading activities, landslides, and channel-bed scouring with minor contributions from slope erosion (Fahey and Marden 2006; Fransen et al. 2001; Marden et al. 2006). For example, there was an eight-fold increase in sediment yields from harvesting in a Hawke's Bay catchment (Figure 3) and a five-fold increase in sediment yields in Separation Point Granites in Nelson (not graphed), compared with pre-harvest sediment yields (Basher et al. 2011; Fahey and Marden 2006). Sediment yields elevated by harvesting activities typically returned to pre-harvest levels, or declined markedly, within two to six years of harvest (Basher et al. 2011; Fahey and Marden 2006; Phillips et al. 2005).

Graynoth (1979) and Thompson et al. (2009) both measured increases in stream bed sedimentation after 


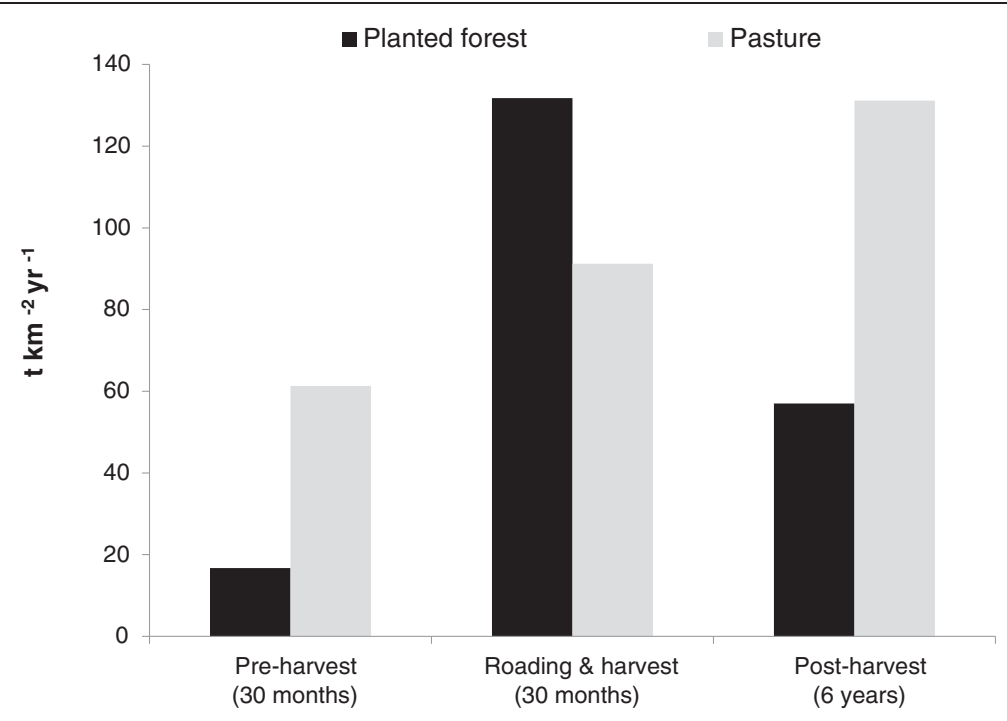

Figure 3 Estimated sediment yields from harvesting activities in a Hawke's Bay hill country planted forest catchment (time periods for each activity are in brackets) compared with an adjacent pasture catchment. The figure is based on data from Fahey \& Marden (2006).

harvesting. In the case of Baillie (2006), headwater streams were still impacted by sediment six years after harvest where woody debris and re-generating vegetation retained sediment within the stream channel. Recovery time will depend on shading out and die back of vegetation in the channel caused by the next rotation of trees, decomposition of woody debris and the capacity of the streams to flush sediment from the system. In spite of large increases in sediment yield during the harvest period (Figure 3), Fahey and Stansfield (2006) found no significant changes in water clarity, turbidity and suspended sediment after harvest. One possible explanation is that most suspended sediment was exported during elevated flows (Fahey et al. 2003; Phillips et al. 2005), and was occasionally captured during routine water quality monitoring.

Nutrients Increases in nutrients, particularly $\mathrm{N}$ and $\mathrm{P}$, typically follow clear-cut harvest operations up to the stream edge as a result of disruption to nutrient cycles and increased leaching and sediment transport into water ways (Gundersen et al. 2006; Hartman 2004; Pike et al. 2010). Many studies have been confined to specific regions (Figure 1). For example, Graynoth (1979) recorded average $\mathrm{NO}_{3}-\mathrm{N}$ concentrations of 0.12 and $0.36 \mathrm{~g} \mathrm{~m}^{-3}$ in two Nelson streams after clear-cut harvesting to the stream edge compared with the un-harvested control site concentration of $0.05 \mathrm{~g} \mathrm{~m}^{-3}$. The TP concentrations showed little response remaining below $0.05 \mathrm{~g} \mathrm{~m}^{-3}$. Thompson et al. (2009) also recorded an increase in $\mathrm{NO}_{3}$ $\mathrm{N}$ (average of $1.43 \mathrm{~g} \mathrm{~m}^{-3}$ ) two years after harvesting at four Otago/Southland streams compared with a pre-harvest average of $0.30 \mathrm{~g} \mathrm{~m}^{-3}$. Collier and Bowman (2003) found the effects of harvesting on dissolved organic carbon, $\mathrm{NO}_{3}$ $\mathrm{N}$ and DRP were short-term (recovery within six months of harvesting) in spring-fed central North Island streams. Post-harvest nutrient increases do not occur in all cases. A Hawke's Bay hill-country catchment showed no significant changes in TP, soluble reactive $\mathrm{P}$, total nitrogen (TN), $\mathrm{NO}_{3}-\mathrm{N}$, or $\mathrm{NH}_{4}-\mathrm{N}$ (Ammonium-nitrogen) after harvesting (Fahey and Stansfield 2006) possibly attributable to the BMPs employed during the harvest operation (Eyles and Fahey 2006) and there were no significant increases in $\mathrm{NO}_{3}-\mathrm{N}$ after harvest of a small central North Island catchment with a high background concentrations of $\mathrm{N}$ (Parfitt et al. 2002).

Biological attributes The physio-chemical changes in water quality following forest harvest to the stream edge produce a range of biological responses. Increased periphyton production in response to elevated in light, temperature and nutrient concentrations, often peaked in the first two to five years after harvest (Boothroyd et al. 2004; Death and Death 2006; Graynoth 1979; Reid et al. 2010; Thompson et al. 2009). Invertebrate densities and biomass frequently increased after harvest in response to increased primary productivity and in-stream organic matter. However, factors such as warmer and more variable temperature regimes and increases in fine sediment often initiated a shift of aquatic invertebrate community composition to those more closely associated with open pasture sites. Sensitive EPT taxa were replaced by taxa (predominantly Chironomidae, Oligochaetes and Mollusca) more tolerant of disturbances associated with harvesting (Baillie et al. 2005; Collier and Bowman 2003; Death et al. 2003; Graynoth 1979; Quinn et al. 2004; 
Thompson et al. 2009). A Nelson study also recorded a decline in freshwater crayfish (Paranephrops planifrons) (Graynoth 1979).

Spatial and temporal effects of harvesting The spatial and temporal distribution of harvesting activities within a planted forest landscape influences both the magnitude of stream ecosystem response and the subsequent recovery rate (Collier and Smith 2005; Reid et al. 2010). Progressive harvesting over a nine to ten year period in two North Island catchments increased the amount of fine sediment, wood and macrophytes in these stream systems along with a decline in the percentage EPT abundance and an increase in the percentage abundance of Elmidae (Collier and Smith 2005). In the Coromandel area, Reid et al. (2010) found the greatest changes to aquatic invertebrate communities following harvest occurred at a threshold catchment size of $<500$ ha and an upstream harvest area of $>40 \%$ of the catchment, particularly when clear-cut harvesting to the stream edge. There was a significant decline in QMCI as the proportion of area harvested upstream increased. While invertebrate communities in catchments $<100$ ha in size had largely recovered to pre-harvest characteristics within 8 years of harvest, recovery was slower in some larger catchment sites. Restoration of shade and associated thermal regimes are likely factors influencing this recovery rate. Contributing factors such as regional variation in geology and hydrology, previous land-use, and inter-annual variation also influenced aquatic invertebrate response in both these studies (Collier and Smith 2005; Reid et al. 2010).

Conversely, in the Hawke's Bay region it was the small headwater streams that took longer to recover from harvesting activities. Invertebrate community characteristics were still affected six years after harvest where channels were impacted by sediment deposition and logging slash, whereas harvesting had little effect on channel morphology at the base of the catchment, and invertebrate community characteristics had recovered within four to five years (Baillie 2006; Death and Death 2006).

Climate change forecasts predict an increase in the frequency of extreme weather events with greatest risks associated with harvesting of planted forests in highly erodible and steep topography (Dunningham et al. 2012). Extreme weather events over large spatial scales can override the effects of land use, including harvesting activities (Basher et al. 2011) and are likely to prolong post-harvest recovery of water quality in streams.

\section{Streamside Management Zones (SMZs)}

Streamside management zones encompass the stream channel and adjacent land area and are actively managed for a range of functions and processes (Neary et al. 2011). In New Zealand, several studies have found that the retention of intact vegetated riparian areas (riparian buffers) within SMZs during harvest operations were effective at maintaining the low light regimes associated with forested streams (Boothroyd et al. 2004; Graynoth 1979; Thompson et al. 2009). They also providing a substantial buffer to changes in stream-water temperature often associated with clear-cut harvesting. Riparian widths as narrow as $10 \mathrm{~m}$ limited input of organic matter from harvesting activities and contributed to the maintenance of channel bank stability (Boothroyd et al. 2004; Thompson et al. 2009). The capacity of riparian buffers to filter out sediment from point-source pollution was limited however. For example, while a $30-150 \mathrm{~m}$ wide buffer at a harvested site in Nelson was effective in maintaining substrate composition, it was ineffective in excluding point-source sediment from a skid site or finer suspended sediment (from point-source routing of runoff along skid trails) from the stream channel (Graynoth 1979). Fine sediment inputs also increased at a Southland site with a $10 \mathrm{~m}$ riparian buffer (Thompson et al. 2009), but increases in $\mathrm{NO}_{3}-\mathrm{N}$ and DRP concentrations were less than that in clear-cut sites. Riparian buffers can however, mitigate the post-harvest pulse in $\mathrm{NO}_{3}-\mathrm{N}$ that occur at some sites with variable ability to reduce DRP concentrations, particularly where post-harvest increases may have been associated with elevated levels of suspended sediment (Graynoth 1979, Thompson et al. 2009). Retention of riparian buffers in SMZs were effective in limiting periphyton production and maintaining invertebrate communities with similar characteristics to those in mature pine and indigenous forest streams (Boothroyd et al. 2004; Graynoth 1979; Quinn et al. 2004). In Southland, a 10-m riparian buffer reduced the magnitude of invertebrate community changes that occurred in a clear-cut site (Thompson et al. 2009).

To date, studies have focused predominantly on harvesting in steeper hill country in New Zealand's planted forests (i.e. Baillie et al. 2005; Boothroyd et al. 2004; Eyles and Fahey 2006; Graynoth 1979; Quinn et al. 2004; Thompson et al. 2009) and less so on the areas of flat to rolling topography (i.e. Collier and Bowman 2003; Pruden et al. 1990). Consequently, there is potential bias in the published information on the extent of environmental impacts of harvesting on waterways in New Zealand's planted forests.

\section{Water quality and land-use comparisons}

Studies comparing water quality in New Zealand's planted forests with other land uses have typically considered mature planted forests with either indigenous forest or pasture (and occasionally tussock grasslands). The same approach is adopted here.

Physical attributes Forest type has little effect on light levels reaching streams with median light levels of $<8 \%$ 
measured in both planted and indigenous forest streams compared with median light levels up to $45 \%$ for streams flowing through pasture (Boothroyd et al. 2004; DaviesColley and Quinn 1998; Quinn et al. 1997).

As a result, stream temperatures were usually higher in pasture streams compared with both planted and indigenous forest streams. In the Waikato region, daily mean temperature averaged $15^{\circ} \mathrm{C}$ in pasture streams, around $2^{\circ} \mathrm{C}$ higher than in indigenous and planted forest streams. Daily maximum temperatures were 6 to $7^{\circ} \mathrm{C}$ higher in pasture streams with maximum temperatures often exceeding $20^{\circ} \mathrm{C}$. By contrast, water temperatures rarely exceeded $15^{\circ} \mathrm{C}$ in forested streams. However there was little difference in daily minimum temperatures among the three land uses (Quinn et al. 1997). Similar results were observed in the Gisborne (Parkyn et al. 2006), Hawke's Bay (Fahey and Stansfield 2006), Nelson (Young et al. 2005) and Canterbury (Harding and Winterbourn 1995) regions.

While differences in sediment concentrations were evident among land uses (Table 3), results were influenced by underlying geology, slope stability and storm patterns during the monitoring period. Highest suspended sediment concentrations and turbidity and sediment yields were usually associated either with pasture land use (Table 3) or underlying highly erodible geologies (Parkyn et al. 2006). Conversely, lower sediment figures were associated with catchments in planted or indigenous forests (Table 3) or porous geologies such as the volcanic regions in the central North Island and the Moutere gravels in the Nelson region (Hicks 1990). In the Hawke's Bay region sediment yields from a pasture catchment (mainly from shallow landslides and stream bank erosion) were estimated to exceed yields from a planted forest catchment over the duration of a forestry cycle in spite of the short-term elevated sediment yields during harvesting (Figure 3) (Eyles and Fahey 2006).

Table 3 Comparison of sediment attributes among streams in planted forest, indigenous forest or pasture ${ }^{1}$

\begin{tabular}{|c|c|c|c|}
\hline \multirow{3}{*}{ Land use } & \multicolumn{3}{|c|}{ Water Quality Parameter } \\
\hline & $\begin{array}{l}\text { Turbidity } \\
\text { (NTU) }\end{array}$ & $\begin{array}{l}\text { Suspended } \\
\text { sediment }\left(\mathrm{g} \mathrm{m}^{-3}\right)\end{array}$ & $\begin{array}{l}\text { Sediment yield } \\
\left(\mathrm{t} \mathrm{km}^{-2} \mathrm{yr}^{-1}\right)\end{array}$ \\
\hline & \multicolumn{3}{|l|}{ Range } \\
\hline Mature planted forest & $0.8-100$ & $0.5-100$ & $1.7-65$ \\
\hline Indigenous forest & $0.3-3.5$ & $0.5-2.5$ & $5.1-160$ \\
\hline Pasture & $1-580$ & $2-700$ & $4.3-106$ \\
\hline
\end{tabular}

${ }^{1}$ The range of mean or median values were derived from tables and text or estimated from figures in references (Dons 1987; Fahey and Marden 2006; Hicks 1990; Quinn et al. 1997; O'Loughlin et al. 1978; Parkyn et al. 2006; Townsend et al. 1997; Young et al. 2005). Sediment yields in O'Loughlin et al. (1978)) were converted from $\mathrm{m}^{3} \mathrm{~km}^{-2} \mathrm{yr}^{-1}$ to $\mathrm{t} \mathrm{km}^{-2} \mathrm{yr}^{-1}$ using $1.7 \mathrm{t} \mathrm{m}^{-3}$. Conversion figure derived from Phillips et al (2005).
Nutrients The range of $\mathrm{TN}, \mathrm{NO}_{3}-\mathrm{N} / \mathrm{NO}_{\mathrm{x}}-\mathrm{N}$ (oxidisednitrogen) and ammoniacal nitrogen $(\mathrm{Amm}-\mathrm{N}) / \mathrm{NH}_{4}-\mathrm{N}$ concentrations in streams in planted forest catchments were similar to indigenous forest streams and generally lower than those in pasture catchments with their more intensive fertiliser and animal stocking regimes (Figure 4a). However, in a central North Island study, the trend was reversed for $\mathrm{NO}_{3}-\mathrm{N}$, with highest concentrations recorded in the indigenous forest site (pasture = $0.013 \mathrm{~g} \mathrm{~m}^{-3}$; planted forest $=0.176 \mathrm{~g} \mathrm{~m}^{-3}$; native forest $=$ $0.805 \mathrm{~g} \mathrm{~m}^{-3}$ ) (Cooper and Thomsen 1988; Cooper 1986; Cooper and Cooke 1984). The authors attributed this difference to denitrification by vegetation in the pasture and planted forest stream channels and suppression of $\mathrm{NO}_{3}-\mathrm{N}$ formation in the planted forest soils influenced by the presence of tree root systems.

Total P concentrations showed a similar land use pattern to TN (Figure 4b). Concentrations of DRP showed little difference between the three land-uses and were below $0.021 \mathrm{~g} \mathrm{~m}^{-3}$ (Figure $4 \mathrm{~b}$ ), although in Matheson et al.'s (2011) study, total DRP concentrations in indigenous forest streams were significantly lower than those in planted forest or pasture streams $(0.019,0.068$ and $0.084 \mathrm{~g} \mathrm{~m}^{-3}$ respectively).

Land-use also influenced the timing and forms of nutrient export with $\mathrm{N}$ and $\mathrm{P}$ mainly transported in dissolved forms during baseflow conditions from a planted forest and indigenous forest catchment with most of the $\mathrm{N}$ and $\mathrm{P}$ export from the pasture catchment occurring in particulate forms during storm events (Cooper and Thomsen 1988).

Biological attributes Underlying water quality attributes influenced by land use such as stream lighting, water temperature, sediment, organic matter and nutrients were key factors driving differences in primary productivity, community respiration, and biological community compositions between streams in forested and pasture catchments (Friberg et al. 1997; Harding and Winterbourn 1995; Parkyn et al. 2006; Quinn et al. 1997; Young and Huryn 1999).

Streams flowing through Waikato hill-country pasture had significantly higher gross photosynthetic rates and periphyton biomass than streams in either indigenous or planted forests (Quinn et al. 1997). Similar land-use effects on algal productivity were evident in other regions of New Zealand (Death et al. 2003; Thompson and Townsend 2004). However, in the Otago region, streams in planted forests supported higher algal biomass than those in pasture, tussock or indigenous forests (although this difference was not statistically significant) (Townsend et al. 1997), and in the Canterbury region no significant differences were found in algal biomass between streams in pasture, scrub or forested catchments (Harding and 

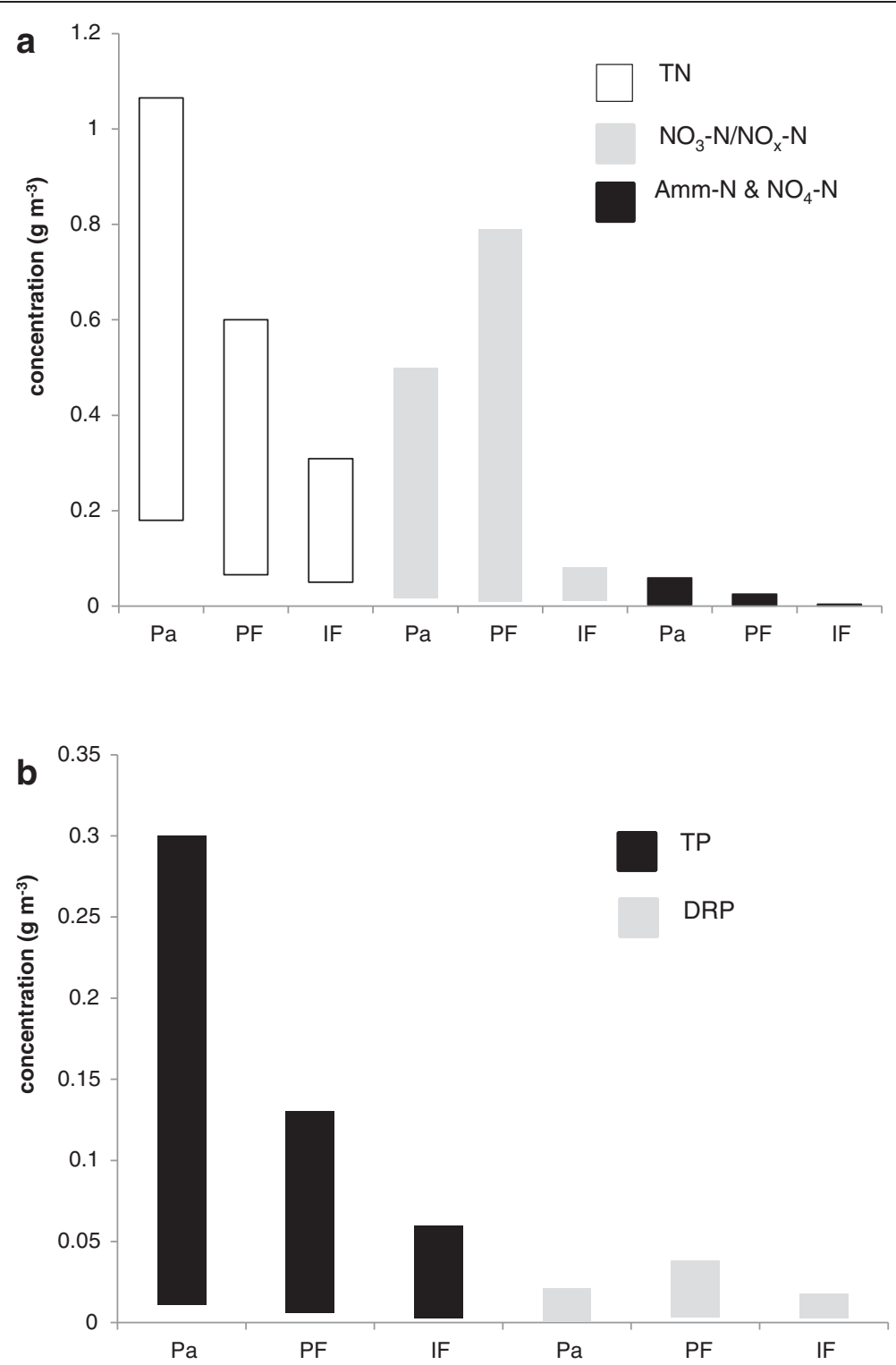

Figure 4 Range of $\mathrm{TN}_{1} \mathrm{NO}_{3}-\mathrm{N}(\mathbf{a}), \mathrm{TP}$ and DRP (b) mean and median concentrations recorded in pasture (Pa) $(n=33)$, mature planted forest (PF) $(n=53)$ and indigenous forest $(I F)(n=35)$ streams. $\mathrm{NO}_{x}-\mathrm{N}$ values have been aggregated with $\mathrm{NO}_{3}-\mathrm{N}$ as nitrite is rapidly oxidised to nitrate and typically comprises a small portion of oxidised-N. Similarly Amm-N values have been aggregated with $\mathrm{NH}_{4}-\mathrm{N}$ values as $\mathrm{NH}_{3}-\mathrm{N}$ comprises a small component of Amm-N. Mean and median concentrations derived from tables and text or estimated from figures in references (Fahey and Stansfield 2006; Friberg et al. 1997; Macaskill et al. 1997; Matheson et al. 2011; Parkyn et al. 2006; Thompson and Townsend 2004b; Townsend et al. 1997; Young et al. 2005). The anomaly of a wider range of $\mathrm{NO}_{3}-\mathrm{N} / \mathrm{NO}_{\mathrm{x}}-\mathrm{N}$ concentrations than $\mathrm{TN}$ concentrations in planted forest streams (Figure 4a) was influenced by Fahey \& Stansfield's (2006) Hawke's Bay study and probably due to the lower sampling intensity of TN, capturing a smaller range of concentrations compared with $\mathrm{NO}_{3}-\mathrm{N}$ (sample size for $\mathrm{NO}_{3}-\mathrm{N}$ and $\mathrm{TN}, 62-64$ and 3-4 respectively).

Winterbourn 1995). In the latter study, the author's suggested that the dense riparian grasses shading the pasture stream channels may have been influencing these results.

Greater concentrations of E. coli are generally found in streams running through pasture land due to animal stocking in the catchment, than streams in forested catchments (Donnison et al. 2004; Parkyn et al. 2006; Young et al. 2005). However, E. coli concentrations in both planted forest and indigenous forests stream did exceed stock drinking and recreational guidelines on certain occasions. The mostly likely sources of bacteria were feral animals and birds.

Streams in pasture catchments often supported higher densities of aquatic invertebrates than those in forested sites (Figure 5a) mainly in response to the higher enrichment and productivity in these streams. Invertebrate communities were characterised by high abundances of more pollution tolerant taxa such as Chironomidae, 

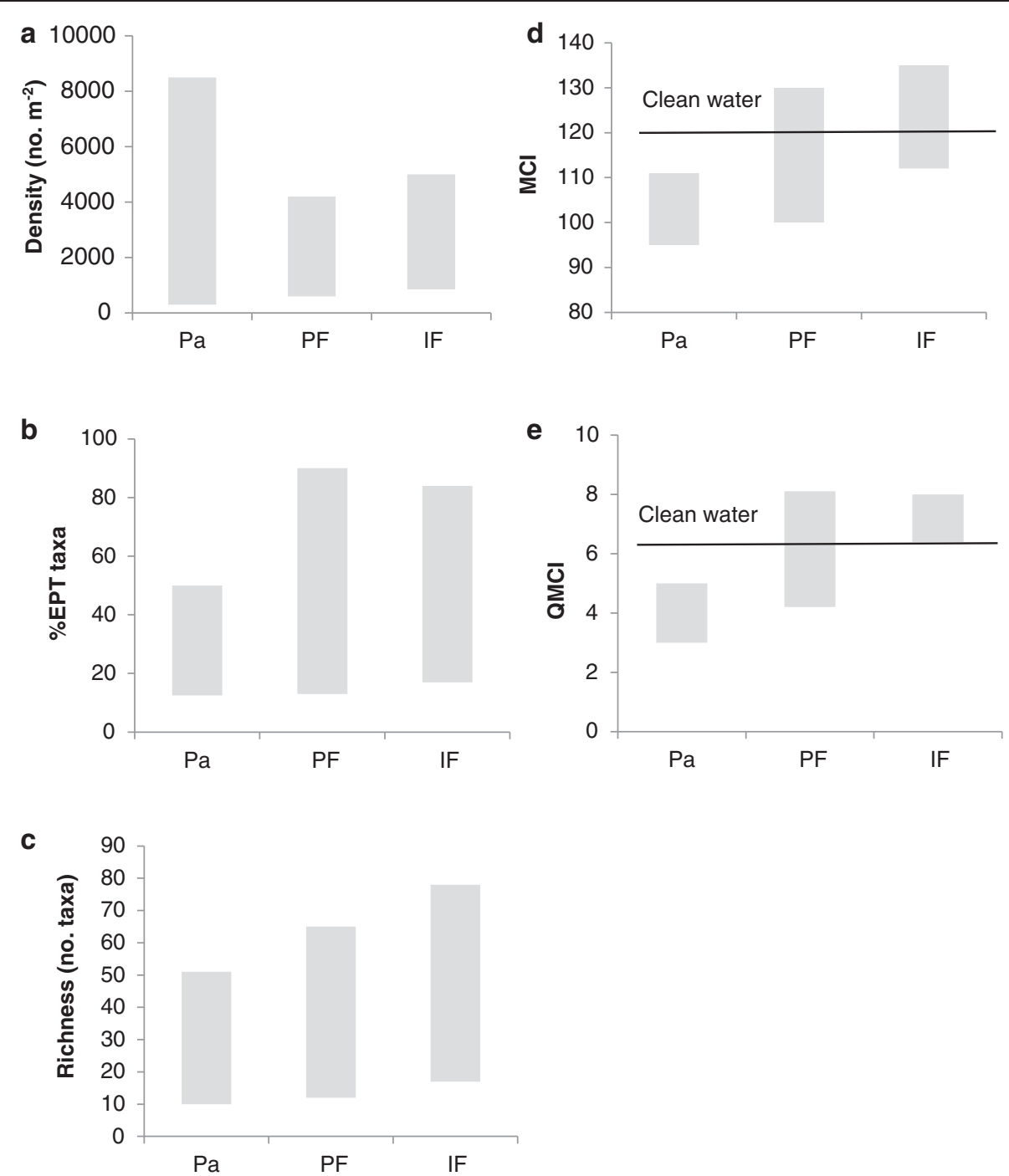

Figure 5 Range of aquatic invertebrate densities (a), percentage EPT taxa (b), taxa richness (c), MCl (d), and QMCl (e) in pasture (Pa), mature planted forest (PF) and indigenous forest (IF) streams. Mean and median values derived from tables and text or estimated from figures in references (Death et al. 2003; Friberg et al. 1997; Harding and Winterbourn 1995; Parkyn et al. 2006; Quinn et al. 1997; Shearer and Young 2011; Stark and Maxted 2007; Townsend et al. 1997).

Mollusca, and Diptera (Death et al. 2003; Friberg et al. 1997; Harding and Winterbourn 1995; Parkyn et al. 2006). The aquatic invertebrate indices in Figure 5(b-e) were generally indicative of improving water quality from pasture to planted forest to indigenous forest. Only streams in indigenous forest catchments consistently had MCI or QMCI scores above the level indicative of 'clean water'. In some studies, the differences in \%EPT taxa, EPT density, MCI and QMCI between pasture and forested streams were significant (Parkyn et al. 2006; Quinn et al. 1997; Shearer and Young 2011).

Land-use comparisons with national water quality standards Many water quality research publications lack the long-term data sets needed to benchmark the performance of different land-uses against national water quality standards and guidelines. Ballantine et al. (2010) and Larned et al. (2004) used long-term national and regional water quality datasets for these types of analyses and found that $\mathrm{TN}, \mathrm{NO}_{\mathrm{x}}-\mathrm{N}, \mathrm{HN}_{4}-\mathrm{N}, \mathrm{DRP}$ and $E$. coli concentrations were significantly higher and water clarity significantly lower in pasture and urban sites compared with planted and indigenous forests (Ballantine et al. 2010; Larned et al. 2004). Pasture and urban sites exceeded national water standards for all these water quality parameters, whereas indigenous forest sites exceeded national water quality guideline for $E$. coli concentrations and planted forests for conductivity (guideline of $175 \mu \mathrm{S} / \mathrm{cm}$ ). Given the influence of geology on conductivity in mature planted forests (Figure 6) and the 


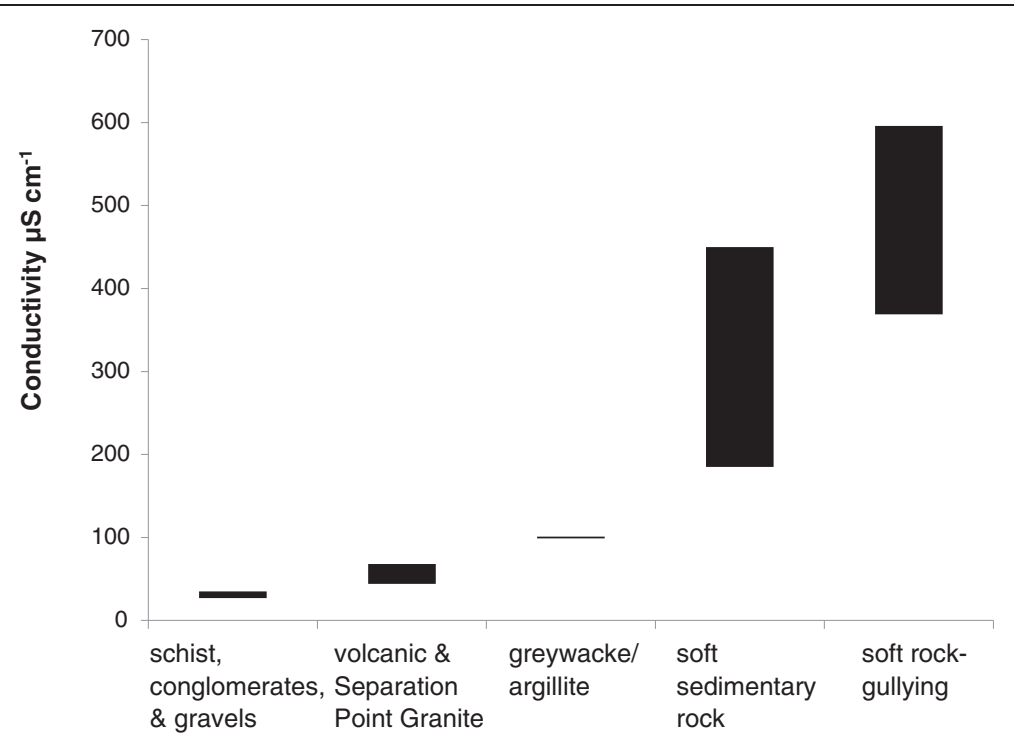

Figure 6 Conductivity in mature planted forest streams across a range of geologies. Mean or median values derived from tables and text or estimated from figures in references (Collier and Halliday 2000; Fahey and Stansfield 2006; Friberg et al. 1997; Harding and Winterbourn 1995; Parkyn et al. 2006; Pruden et al. 1990; Young et al. 2005).

establishment of planted forests in many areas of New Zealand on steep, highly erodible land, sediment concentrations are a likely factor influencing these results.

National and regional water quality monitoring sites for planted forests are often established in larger catchments where planted forests may be the dominant, but not necessarily the only land use in the catchment which may influence results. Monitoring in larger catchments also limits the ability to detect temporal changes in water quality that occur throughout a forestry cycle at the smaller spatial scale. In contrast, research papers on water quality in planted forests usually focus on smaller catchments entirely in planted forests. These more detailed studies provide information on a wider range of attributes than can be reported on nationally, and capture the temporal and spatial variability inherent in planted forests. Therefore, considering results from both national and research focused studies provides the best depiction of water quality in planted forest streams.

Land-use effects on lakes and wetlands Lakes and wetlands lack the flushing capacity of streams and rivers and are inherently more susceptible to effects of land management activities. Overall, water quality in lakes across New Zealand is declining (Verburg et al. 2010). Abell et al.'s (2011) survey of 101 lakes across New Zealand showed that while high producing pasture land had the greatest effect on lake nutrient status, concentrations of TP were positively correlated with the percentage of planted forest in the catchment and exceeding the naturally high background rates of $\mathrm{P}$ associated with underlying volcanic geology. In addition, most particulate forms of $\mathrm{P}$ are usually exported during high flow events, so regular water quality monitoring programmes may underestimate $\mathrm{P}$ export from planted forests to downstream environments such as lakes. The authors suggested that the legacy from historical forest clearance and previous land use may also be influencing these results.

The influence of planted forests on the water quality in a range of lotic water bodies (including wetlands) in the Otago region of the South Island was less obvious (Galbraith and Burns 2007). Although water quality from planted forests was more closely associated with pasture and urban areas than indigenous vegetation in ordination space, correlations between nutrient concentrations and the percentage of the catchment in planted forest were either weak or absent. Verburg et al. (2010) also found no significant correlations between the percentage of planted forest land cover and the Trophic Lake Index (TLI) and its components of TN, TP and chlorophyll $a$. However, in catchments where planted forest formed the dominant land cover, lakes supported higher levels of macrophytes as measured by the submerged plant index (SPI).

\section{Knowledge gaps}

Interpretation of results from studies in planted forests was often hindered by a lack of information on factors such as underlying geology, hydrology, previous land use, stand age, and forest management and harvesting practices. In order to reduce the risk of arriving at erroneous conclusions, understanding the influence of those factors on water quality attributes is very important 
when assessing the consequences of forestry practices on stream environments and comparing the effects of different land-uses on waterways.

A number of specific knowledge gaps were identified in the course of this review effort. The principal ones are as follows:

- As the potential risks to water quality are greatest during harvesting and the immediate post-harvest period, future research to minimise impacts on water quality during this phase of the forestry cycle remains a priority in New Zealand.

- Some of the global emerging issues in water quality include ground and surface water contamination from pesticides, pharmaceuticals, and heavy metals (Vörösmarty et al. 2010; Winkworth 2013; Gothwal \& Shashidhar 2014; Sanderson et al. 2004). Mossop et al. (2013) concluded that forested catchments have few of these issues at the present time but they should be monitored periodically. In New Zealand, potential interventions to increase the productivity of planted forests such as immune system stimulants, plant growth promoting agents, and intensified use of fertilisers and pesticides along with possible pharmaceutical contamination from land application of biosolids (pers. comm., G. Coker, Scion; Gielen et al. 2009), highlight a suite of prospective contaminants in water bodies seldom investigated in water quality studies in New Zealand's planted forests.

- There is growing world-wide recognition of the value of ecosystem services provided by planted and indigenous forests and the freshwater ecosystems within them (Dissmeyer 2000; Foley et al. 2005; Wilson and Carpenter 1999, Yao et al. 2013). Consequently, there is a need to identify and value the ecosystem services provided to New Zealand's society from the freshwater resources in $\mathrm{New}$ Zealand's planted forests.

- Research is lacking on the effectiveness of the latest BMPs, technologies, rules and regulations, and regional and national policies on mitigating the effects of management activities (particularly harvesting) on water quality in planted forest waterways.

- Further research is needed to manage/reduce/ mitigate the impacts of extreme weather events on waterways in planted forests. These types of events are predicted to increase in some areas of New Zealand in response to climate change.

- The few studies on the effects of management activities on freshwaters during the establishment and growing phase of the forestry cycle are limited in scope and dated. There is limited information on the effects of current management practices, such as chemical and fertiliser application rates, on freshwater resources.

- While a number of studies have evaluated the effectiveness of riparian buffers within SMZs in mitigating harvesting disturbances in New Zealand, information on the appropriateness and effectiveness of different buffer widths is lacking (Richardson et al. 2012). In particular, the effectiveness of the current minimum 5-m setback (Forest Owners Association 2007) in mitigating harvest impacts has never been fully evaluated.

- Most of the research on water quality is in catchments of $P$. radiata. There is a lack of information on the effects of other tree species on freshwater environments.

- Wetlands in New Zealand have been greatly reduced by historical forest clearance and changes in land use (McGlone 2009). However, wetlands still remain in planted forests and published information is lacking on their status and the influence of forest management activities on water quality.

- Freshwater biodiversity is under threat worldwide (Dudgeon et al. 2006). Given the similarities between mature planted forest and indigenous forest stream ecosystems, it is likely that the biodiversity potential of planted forest streams is under-rated. Therefore, research is needed to quantify and value the aquatic biodiversity in New Zealand's planted forests.

\section{Discussion and conclusions}

Forested catchments, both indigenous and planted, are known world-wide for producing high quality water (Dissmeyer 2000; Dudley and Stolton 2003; Webb et al. 2012). This review showed that New Zealand's planted forests also produce high water quality for a large proportion of the forestry-growing cycle. The fact that planting forests can rapidly (within 5-6 years) improve water quality from land previously in pasture highlights the potential of this land use as a remedial tool for degraded waterways.

However, the inherent cyclical nature of planted forests in New Zealand can result in adverse changes in water quality at certain points during a rotation, particularly when clear-cut harvesting up to stream edges. Where comparable forestry practices are used overseas, similar effects on water quality attributes and recovery times have also been documented (Hartman 2004; Martin et al. 2000; Neary 2012 and references therein). However, improvements in management practices, the implementation of water-quality thresholds, use of alternate harvesting systems (such as selective harvesting and small harvesting coupes), retention of riparian buffers or limited harvesting activities in SMZs have, in a number of cases, effectively mitigated the impacts of harvesting 
on water quality (Aust and Blinn 2004; Broadmeadow and Nisbet 2004; Kreutzweiser and Capell 2001; Little et al. 2014; Neary et al. 2010; Pike et al. 2010).

While the retention of riparian buffers within SMZs mitigated many of the effects of clear-cut harvesting alongside New Zealand streams, a legacy of planting along stream margins means that harvesting up to the stream edge still occurs throughout New Zealand's planted forests. Economic constraints limit the use of selective harvesting and small harvesting coupes. Retaining an intact riparian buffer during harvesting remains a challenge in some of the steeper, less accessible areas of planted forests in New Zealand, where roading constraints necessitate the extraction of timber across headwater catchments. Greatest gains in water quality will be from advances in harvesting systems and BMPs that eliminate or mitigate harvesting risks, particularly in the steeper forested areas.

New Zealand is ranked among the top ten countries of the world in terms of its water resources based on access to water, water quality (parameters: DO, EC, $\mathrm{pH}$ TP, $\mathrm{TN}$ ), water stress and water scarcity indices (Emerson et al. 2010). However, in-line with global trends (Foley et al. 2005; Vörösmarty et al. 2010), New Zealand faces increasing pressure on its freshwater resources particularly with the intensification of forestry, agricultural, and urban activities (Ballantine et al. 2010; Larned et al. 2004; Parris 2011; Swaffield 2013). These pressures are the impetus behind a series of national reforms on water management currently underway in New Zealand (New Zealand Government 2014). New Zealand will see more community-based decision-making processes around the use of its freshwater resources and setting of 'national bottom lines' for some water quality attributes. While planted forests can potentially affect water yield (Davie and Fahey 2005; van Dijk and Keenan 2007), they produce high water quality for a large component of the forestry cycle, providing a valuable community service to downstream users.

The New Zealand forest industry has a long-term vision to sustainably double productivity on a per hectare basis from its forest estate (Forest Owners Association 2012). Implicit in achieving this vision will be the challenge to continue to provide a sustainable source of wood and fibre along with the provision of wellmaintained and high quality water resources. Having healthy and productive forests is particularly important in the face of increasing global wood demand trends and forest certification requirements.

\section{Competing interests}

The authors declare that they have no competing interests.

\section{Authors' contributions}

BB has undertaken the literature review for this manuscript, including the collation of review literature, the summarizing, analysis, and interpretation of the review information and has led the writing of this paper. DN has contributed to the design of literature review, the collation of review literature, the summarizing, analysis and interpretation of the review information and participated in the writing of the manuscript. All authors read and approved the final manuscript.

\section{Acknowledgements}

This work was funded by the Ministry of Business, Innovation and Employment (MBIE) 'Protecting and enhancing the environment through forestry' programme C04X0806. We would like to thank various authors of papers in this review for assisting with enquiries and information requests. Russell Death and Keith Moser reviewed earlier versions of the manuscript. Duncan Harrison compiled the data on stream kilometres in New Zealand's planted forests.

\section{Author details}

${ }^{1}$ SCION, Private Bag 3020, Rotorua 3046, New Zealand. ' USDA Forest Service, Rocky Mountain Research Station, 2500 South Pine Knoll Drive Flagstaff, Arizona 86001, USA.

Received: 18 August 2014 Accepted: 23 April 2015

Published online: 22 May 2015

\section{References}

Abell, JM, Özkundakci, D, Hamilton, DP, \& Miller, SD. (2011). Relationships between land use and nitrogen and phosphorus in New Zealand lakes. Marine and Freshwater Research, 62, 162-175.

Allan, JD, \& Castillo, MM. (2009). Stream ecology: structure and function of running waters (2nd ed.). The Netherlands: Springer.

Aust, WM, \& Blinn, CR. (2004). Forestry best management practices for timber harvesting and site preparation in the eastern United States: an overview of water quality and productivity research during the past 20 years (1982-2002). Water, Air, and Soil Pollution: Focus, 4(1), 5-36.

Baillie, B. (2006). Forestry effects on channel morphology and channel vegetation. In G Eyles \& B Fahey (Eds.), The Pakuratahi land use study (pp. 75-89). Napier, New Zealand: Hawke's Bay Regional Council.

Baillie, BR. (2011). The physical and biological function of wood in New Zealand's forested stream ecosystems. New Zealand: Doctor of Philosophy, The University of Waikato.

Baillie, BR, Collier, KJ, \& Nagels, J. (2005). Effects of forest harvesting and woody debris removal on two Northland streams, New Zealand. New Zealand Journal of Marine and Freshwater Research, 39, 1-15.

Baillie, BR, Neary, DG, Gous, S, \& Rolando, CA. (2015). Aquatic fate of aerially applied hexazinone and terbuthylazine in a New Zealand planted forest. Journal of Sustainable Watershed Science \& Management, 2(1), 118-129.

Ballantine, DJ, Booker, D, Unwin, M, \& Snelder, T. (2010). Analysis of national river water quality data for the period 1998-2007 (NIWA Client Report: CHC2010-038). Wellington, New Zealand: Prepared for the Ministry for the Environment.

Basher, LR, Hicks, DM, Clapp, B, \& Hewitt, T. (2011). Sediment yield response to large storm events and forest harvesting, Motueka River, New Zealand. New Zealand Journal of Marine and Freshwater Research, 45(3), 333-356.

Binkley, D, Burnham, H, \& Allen, LH. (1999). Water quality impacts of forest fertilization with nitrogen and phosphorus. Forest Ecology and Management, $121,191-213$

Blaschke, P, Hicks, D, \& Meister, A. (2008). Quantification of the flood and erosion reduction benefits, and costs, of climate change mitigation measures in New Zealand (Report prepared by Blaschke and Rutherford Environmental Consultants for MfE 2008th ed.). Wellington: Ministry for the Environment.

Boothroyd, I, \& Stark, J. (2000). Use of invertebrates in monitoring. In KJ Collier \& MJ Winterbourn (Eds.), New Zealand stream invertebrates: ecology and implications for management (pp. 344-373). Christchurch, New Zealand: New Zealand Limnological Society.

Boothroyd, IKG, Quinn, JM, Langer, ER, Costley, KJ, \& Steward, G. (2004). Riparian buffers mitigate effects of pine plantation logging on New Zealand streams: 1. Riparian vegetation structure, stream geomorphology and periphyton. Forest Ecology and Management, 194, 199-213.

Broadmeadow, S, \& Nisbet, TR. (2004). The effects of riparian forest management on the freshwater environment: a literature review of best management practice. Hydrology and Earth System Sciences, 8(3), 286-305.

Bulman, LS, Gadgil, PD, Kershaw, DJ, \& Ray, JW. (2004). Assessment and control of Dothistroma needle-blight (Forest Research Bulletin No. 229). Rotorua, New Zealand: Forest Research. 
Campbell, IC, \& Doeg, TJ. (1989). Impact of timber harvesting and production on streams: a review. Australian Journal of Marine \& Freshwater Research, 40, 519-539.

Carr, GM, \& Neary, JP. (2008). Water quality for ecosystem and human health (2nd ed.). Ontario, Canada: United Nations Environment Programme/Earthprint.

Collier, KJ, \& Bowman, EJ. (2003). Role of wood in pumice-bed streams I: impacts of post-harvest management on water quality, habitat and benthic invertebrates. Forest Ecology and Management, 177, 243-259.

Collier, KJ, \& Halliday, JN. (2000). Macroinvertebrate-wood associations during decay of plantation pine in New Zealand pumice-bed streams: stable habitat or trophic subsidy? Journal of the North American Benthological Society, 19(1), 94-111.

Collier, KJ, \& Smith, BJ. (2005). Effects of progressive catchment harvesting on stream invertebrates in two contrasting regions of New Zealand's North Island. Marine and Freshwater Research, 56, 57-68.

Collier, KJ, \& Winterbourn, MJ. (1989). Impacts of wetland afforestation on the distribution of benthic invertebrates in acid streams of Westland, New Zealand. New Zealand Journal of Marine and Freshwater Research, 23, 479-490.

Cooper, BA. (1986). Suppression of nitrate formation within an exotic conifer plantation. Plant and Soil, 93, 383-394.

Cooper, BA, \& Cooke, JG. (1984). Nitrate loss and transformation in 2 vegetated headwater streams. New Zealand Journal of Marine and Freshwater Research, $18,441-450$.

Cooper, AB, \& Thomsen, CE. (1988). Nitrogen and phosphorus in streamwaters from adjacent pasture, pine, and native forest catchments. New Zealand Journal of Marine and Freshwater Research, 22, 279-291.

Cooper, AB, Hewitt, JE, \& Cooke, JG. (1987). Land use impacts on streamwater nitrogen and phosphorus. New Zealand Journal of Forestry Science, 17, 179-192.

Cristea, N, \& Janisch, J. (2007). Modelling the effects of riparian buffer width on effective shade and stream temperatures (Publication No. 07-03-028). Olympia, Washington: Washington State Department of Ecology.

Davie, T, \& Fahey, B. (2005). Forestry and water yield - current knowledge and futher work. New Zealand Journal of Forestry, 49(4), 3-8.

Davies-Colley, RJ, \& Quinn, JM. (1998). Stream lighting in five regions of North Island, New Zealand: control by channel size and riparian vegetation. New Zealand Journal of Marine and Freshwater Research, 32, 591-605.

Davis, M. (2014). Nitrogen leaching losses from forests in New Zealand. New Zealand Journal of Forestry Science, 44(2), 14

Death, R, \& Death, F. (2006). Forestry effects on stream invertebrate communities. In G Eyles \& B Fahey (Eds.), The Pakuratahi land use study (pp. 91-106). Napier, New Zealand: Hawke's Bay Regional Council.

Death, RG, Baillie, B, \& Fransen, P. (2003). Effect of Pinus radiata logging on stream invertebrate communities in Hawke's Bay, New Zealand. New Zealand Journal of Marine and Freshwater Research, 37, 507-520.

Dissmeyer, GE (Ed.). (2000). Drinking water from forests and grasslands: a synthesis of the scientific literature (General Technical Report SRS-39). Southern Research Station, Asheville, North Carolina: United States Department of Agriculture Forest Service,

Donnison, A, Ross, C, \& Thorrold, B. (2004). Impact of land use on the faecal microbial quality of hill-country streams. New Zealand Journal of Marine and Freshwater Research, 38(5), 845-855.

Dons, A. (1987). Hydrology and sediment regime of a pasture, native forest, and pine forest catchment in the central North Island, New Zealand. New Zealand Journal of Forestry Science, 17(2/3), 161-178.

Dudgeon, D, Arthington, AH, Gessner, MO, Kawabata, Z-I, Knowler, DJ, Lévêque, C, Naiman, RJ, Prieur-Richard, A-H, Soto, D, Stiassny, ML, \& Sullivan, CA. (2006). Freshwater biodiversity: importance, threats, status and conservation challenges. Biological Review, 81, 163-182.

Dudley, N, \& Stolton, S. (2003). Running pure: the importance of forest protected areas to drinking water. Gland, Switzerland: World Bank and WWF Alliance for Forest Conservation and Sustainable use.

Dunningham, A, Kirschbaum, M, Payn, T, \& Meason, D. (2012). Chapter 7. Forestry: Long-term adaptation of productive forests in a changing climatic environment. In A Clark \& R Nottage (Eds.), Impacts of climate change on land-based sectors and adaptation options. Technical Report to the Sustainable Land Management and Climate Change Adaptation Technical Working Group. MPI Technical Paper No: 2012/33 (pp. 293-346). Wellington, New Zealand: New Zealand Ministry for Primary Industries.

Emerson, J, Esty, DC, Levy, MA, Kim, C, Mara, V, de Sherbinin, A, Srebotnjak, T, \& Jaiteh, M. (2010). 2010 Environmental Performance Index (Yale Center for Environmental Law and Policy). New Haven: Yale University.
Eyles, G, \& Fahey, B (Eds.). (2006). The Pakuratahi land use study. Napier, New Zealand: Hawke's Bay Regional Council.

Fahey, B, \& Marden, M. (2006). Forestry effects on sediment yield and erosion. In G Eyles \& B Fahey (Eds.), The Pakuratahi land use study (pp. 51-62). Napier, New Zealand: Hawke's Bay Regional Council.

Fahey, B, \& Stansfield, B. (2006). Forestry effects on water quality. In G Eyles \& B Fahey (Eds.), The Pakuratahi land use study (pp. 63-74). Napier, New Zealand: Hawke's Bay Regional Council.

Fahey, BD, Marden, M, \& Phillips, CJ. (2003). Sediment yields from plantation forestry and pastoral farming, coastal Hawke's Bay, North Island, New Zealand. Journal of Hydrology (NZ), 42(1), 27-38.

Fahey, B, Duncan, M, \& Quinn, J. (2004). Impacts of forestry. In JS Harding, MP Mosley, CP Pearson, \& BK Sorrell (Eds.), Freshwaters of New Zealand (pp. 1-16). Christchurch, New Zealand: New Zealand Hydrological Socieyt Inc. and New Zealand Limnological Society Inc.

Feller, MC. (2005). Forest harvesting and streamwater inorganic chemistry in western North America: a review. Journal of the American Water Resources Association, 41(4), 785-811.

Fish, GR. (1968). The hazard presented to freshwater life by aerial copper spraying. New Zealand Journal of Forestry, 13(2), 239-243.

Foley, JA, DeFries, R, Asner, GP, Barford, C, Bonan, G, Carpenter, SR, Chapin, FS, Coe, MT, Daily, GC, Gibbs, HK, Helkowski, JH, Holloway, T, Howard, EA, Kucharik, CJ, Monfreda, C, Patz, JA, Prentice, C, Ramankutty, N, \& Snyder, PK (2005). Global consequences of land use. Science, 309, 570-574.

Forest Owners Association. (2007). New Zealand environmental code of practice for plantation forestry. Wellington, New Zealand: New Zealand Forest Owners Association.

Forest Owners Association. (2012). New Zealand forestry science and innovation plan. Wellington, New Zealand: Forest Owners Association.

Forest Owners Association \& Ministry for Primary Industries. (2013). New Zealand plantation forest industry facts \& figures 2012/2013. Wellington, New Zealand: Forest Owners Association and Ministry for Primary Industries.

Fransen, PJB, Phillips, CJ, \& Fahey, BD. (2001). Forest road erosion in New Zealand: overview. Earth Surface Processes and Landforms, 26, 165-174.

Friberg, N, Winterbourn, MJ, Shearer, KA, \& Larsen, SE. (1997). Benthic communities of forest streams in the South Island, New Zealand: effects of forest type and location. Archiv für Hydrobiologie, 138(3), 289-306.

Galbraith, LM, \& Burns, CW. (2007). Linking land-use, water body type and water quality in southern New Zealand. Landscape Ecology, 22, 231-241.

Gielen, JHP. (2009). Factors impacting on pharmaceutical leaching following sewage application to land. Chemosphere, 74, 537-542.

Gleick, PH. (1993). Water in crisis: a guide to the world's fresh water resources. New York: Oxford University Press.

Gothwal, R, \& Shashidhar, T. (2014). Antibiotic pollution in the Environment: a review. CLEAN-Soil. Air, Water, 42, 1-11.

Graynoth, E. (1979). Effects of logging on stream environments and faunas in Nelson. New Zealand Journal of Marine and Freshwater Research, 13(1), 79-109.

Gundersen, P, Schmidt, IK, \& Rauland-Rasmussen, K. (2006). Leaching of nitrate from temperate forests - effects of air pollution and forest management. Environmental Review, 14, 1-57.

Harding, JS, \& Winterbourn, MJ. (1995). Effects of contrasting land use on physico-chemical conditions and benthic assemblages of streams in a Canterbury (South Island, New Zealand) river system. New Zealand Journal of Marine and Freshwater Research, 29(4), 479-492.

Hartman, GF. (2004). Effects of forest management activities on watershed processes. In TG Northcote \& GF Hartman (Eds.), Fishes and forestry - worldwide watershed interactions and management (pp. 271-302). Oxford: Blackwell Science.

Hicks, MD. (1990). Suspended sediment yields from pasture and exotic forest basins (Vol. 4). Taupo, New Zealand: Paper presented at the Proceedings of the New Zealand Hydrological Society Symposium.

Jackson, RJ. (1987). Hydrology of an acid wetland before and after draining for afforestation, western New Zealand (Paper presented at the Forest Hydrology and Watershed Management, pp. 465-473). Vancouver, Canada: Proceedings of the Vancouver Symposium.

Kreutzweiser, DP, \& Capell, SS. (2001). Fine sediment deposition in streams after selective forest harvesting without riparian buffers. Canadian Journal of Forest Research, 31, 2134-2142.

Landcare Research. (2014). Land Cover Data Base - LCDBv4 GIS Layer. https:// Iris.scinfo.org.nz/layer/412-Icdb-v40-land-cover-database-version-40/. Accessed 23rd April 2015 
Larned, ST, Scarsbrook, MR, Snelder, TH, Norton, NJ, \& Biggs, BJF. (2004). Water quality in low-elevation streams and rivers of New Zealand: recent state and trends in contrasting land-cover classes. New Zealand Journal of Marine and Freshwater Research, 38, 347-366.

Leonard, JH. (1977). Nitrogen run-off from a radiata pine forest fertilised with urea. New Zealand Journal of Forestry, 22(1), 64-80.

Little C, Cuevas, JG, Lara, A, Pino M, \& Schoenholtz, S. (2014). Buffer effects of streamside native forests on water provision in watersheds dominated by exotic forest plantations. Ecohydrology. doi:10.1002/eco.1575.

Macaskill, JB, Cooper, AB, \& Bowman, EJ. (1997). Nitrogen and phosphorus in streams draining catchments of different landuse in the Rotorua Lakes region. Whakatane, New Zealand: NIWA Client Report: BPR 223 prepared for Environment Bay of Plenty.

Maclaren, JP. (1996). Environmental effects of planted forests in New Zealand: the implications of continued afforestation of pasture - Chapter 4 water quality ( $p p$ 27-43). Rotorua, New Zealand: FRI Bulletin No. 198. New Zealand Forest Research Institute.

Manatū Taonga Ministry for Culture and Heritage. (2014). Te Ara - The Encyclopedia of New Zealand. http://www.teara.govt.nz/en. Accessed 24th July 2014.

Marden, M, Rowan, D, \& Phillips, C. (2006). Sediment sources and delivery following plantation harvesting in a weathered volcanic terrain, Coromandel peninsula, North Island, New Zealand. Australian Journal of Soil Research, 44, 219-232.

Martin, CW, Hornbeck, JW, Likens, GE, \& Buso, DC. (2000). Impacts of intensive harvesting on hydrology and nutrient dynamics of northern hardwood forests. Canadian Journal of Fisheries and Aquatic Sciences, 57(S2), 19-29.

Matheson, FE, Tank, JL, \& Costley, KJ. (2011). Land use influences stream nitrate uptake in the Lake Taupo catchment. New Zealand Journal of Marine and Freshwater Research, 45(2), 287-300.

McGlone, MS. (2009). Postglacial history of New Zealand wetlands and implications for their conservation. New Zealand Journal of Ecology, 33(1), 1-23.

Moore, DR, Spittlehouse, DL, \& Story, A. (2005). Riparian microclimate and stream temperature response to forest harvesting: a review. Journal of the American Water Resources Association, 41(4), 813-834.

Mossop, DC, Kellar, C, Jeppe, K, Myers, J, Rose, G, Weatherman, K, Pettigrove, V, \& Leahy, P. (2013). Impacts of intensive agriculture and plantation forestry on water quality in the Latrobe catchment Victoria (p. 64). Melbourne, Australia: EPA Victoria Publication No. 1528.

Neary, DG. (2012). Forest paired catchment studies of water quality: past, present, and future (Paper presented at the Revisiting Experimental Catchment Studies in Forest Hydrology, June-July 2011, Melbourne, Australia. IAHS Publication No. 353, Wallingford, UK. 169-184).

Neary, DG, \& Leonard, JH. (1978). Effects of forest fertilisation on nutrient losses in streamflow in New Zealand. New Zealand Journal of Forestry Science, 8(1), 189-205.

Neary, DG, Ice, GG, \& Jackson, CR. (2009). Linkages between forest soils and water quantity and quality. Forest Ecology and Management, 258, 2269-2281.

Neary, DG, Smethurst, PJ, Baillie, BR, Petrone, KC, Cotching, WE, \& Baillie, CC. (2010). Does tree harvesting in streamside management zones adversely affect stream turbidity? - preliminary observations from an Australian case study. Journal of soils and sediment, 10(4), 652-670.

Neary, DG, Smethurst, PJ, Baillie, B, \& Petrone, KC. (2011). Water quality, biodiversity, and codes of practice in relation to harvesting forest plantations in Streamside Management Zones. Canberra, Australia: CSIRO Special Report.

New Zealand Government (2014). National Policy Statement for Freshwater Management 2014. Wellington, New Zealand: New Zealand Government.

O'Loughlin, C. (1994). The forest and water quality relationship. New Zealand Forestry, 39(3), 26-30.

O'Loughlin, CL, Rowe, LK, \& Pearce, AJ. (1978). Sediment yields from small forested catchments North Westland - Nelson, New Zealand. Journal of Hydrology: New Zealand, 17, 1-15.

Olsen, DA, Tremblay, L, Clapcott, J, \& Holmes, R. (2012). Water temperature criteria for native aquatic biota. Auckland, New Zealand: Auckland Council Technical Report 2012/036.

Parfitt, RL, Salt, GJ, \& Hill, LF. (2002). Clear-cutting reduces nitrate leaching in a pine plantation of high natural N status. Forest Ecology and Management, 170, 43-53.

Parkyn, SM, Davies-Colley, RJ, Scarsbrook, MR, Halliday, NJ, Nagels, JW, Marden, M, \& Rowan, D. (2006). Pine afforestation and stream health: a comparison of land-use in two soft rock catchments, East Cape, New Zealand. New Zealand Natural Sciences, 31, 113-135.
Parris, K. (2011). Impact of agriculture on water pollution in OECD countries: recent trends and future prospects. Water Resources Development, 27(1), 33-52.

Phillips, C, Marden, M, \& Rowan, D. (2005). Sediment yield following plantation forest harvesting, Coromandel Peninsula, North Island, New Zealand. Journal of Hydrology (NZ), 44(1), 29-44

Pike, RG, Feller, MC, Stednick, JD, Rieberger, KJ, \& Carver, M. (2010). Water quality and forest management. In RG Pike, TE Redding, RD Moore, RD Winker, \& KD Bladon (Eds.), BC Ministry of Forests and Range, Forest Science Program, Victoria, BC, and FORREX Forum for Research and Extension in Natural Resources (Vol. 66, pp. 401-440). Kamloops, BC: Land Management Handbook.

Pruden, C, Harding, J, \& Coker, RJ. (1990). Survey of water quality and invertebrate fauna in headwater streams Matea Plateau. Kaingaroa Forest: Landcare Research New Zealand Ltd., Christchurch, New Zealand.

Quinn, JM, \& Wright-Stow, AE. (2008). Stream size influences stream temperature impacts and recovery rates after clearfell logging. Forest Ecology and Management, 256, 2101-2109.

Quinn, JM, Steele, LG, Hickey, CW, \& Vickers, ML. (1994). Upper thermal tolerances of twelve New Zealand stream invertebrate species. New Zealand Journal of Marine and Freshwater Research, 28, 391-397.

Quinn, JM, Cooper, BA, Davies-Colley, RJ, Rutherford, JC, \& Williamson, RB. (1997). Land use effects on habitat, water quality, periphyton and benthic invertebrates in Waikato hill-county streams. New Zealand Journal of Marine and Freshwater Research, 31, 579-597.

Quinn, JM, Boothroyd, IKG, \& Smith, BJ. (2004). Riparian buffers mitigate effects of pine plantation logging on New Zealand streams: 2. Invertebrate communities. Forest Ecology and Management, 191, 129-146.

Quinn, JM, Croker, GF, Smith, BJ, \& Bellingham, MA. (2009). Integrated catchment management effects on flow, habitat, instream vegetation and macroinvertebrates in Waikato, New Zealand, hill-country streams. New Zealand Journal of Marine and Freshwater Research, 43(3), 775-802.

Reid, DJ, Quinn, JM, \& Wright-Stow, AE. (2010). Responses of stream macroinvertebrate communities to progressive forest harvesting: influences of harvest intensity, stream size and riparian buffers. Forest Ecology and Management, 260, 1804-1815.

Resource Management Act. (1991). Statute No. 69. Wellington, New Zealand: New Zealand Parliamentary Counsel Office.

Richardson, J, Boubée, JAT, \& West, DW. (1994). Thermal tolerance and preference of some native New Zealand freshwater fish. New Zealand Journal of Marine and Freshwater Research, 28, 399-407.

Richardson, JS, Naiman, RJ, \& Bisson, PA. (2012). How did fixed-width buffers become standard practice for protecting freshwaters and their riparian areas from forest harvest practices? Freshwater Science, 31(1), 232-238.

Roux, DJ, van Vliet, HR, \& van Veelen, M. (1993). Towards integrated water quality monitoring: assessment of ecosystem health. Water SA, 19(4), 275-280.

Sanderson, H, Johnson, DJ, Reitsma, T, Brain, RA, Wilson, CJ, \& Solomon, KR. (2004). Ranking and prioritization of environmental risks of pharmaceuticals in surface waters. Regulatory Toxicology and Pharmacology, 39, 158-183.

Shearer, KA, \& Young, RG. (2011). Influences of geology and land use on macroinvertebrate communities across the Motueka River catchment, New Zealand. New Zealand Journal of Marine and Freshwater Research, 45(3), 437-454.

Snelder, TH, \& Biggs, BJF. (2002). Multiscale river environment classification for water resources management. Journal of the American Water Resources Association, 38(5), 1225-1239.

Stark, JD, \& Maxted, JR. (2007). A biotic index for New Zealand's soft-bottomed streams. New Zealand Journal of Marine and Freshwater Research, 41, 43-61.

Swaffield, S. (2013). Sustainability practices in New Zealand agricultural landscapes under an open market policy regime. Landscape Research, 39(2), 190-204

Thompson, RM, \& Townsend, CR. (2004). Land-use influences on New Zealand stream communities: effects on species composition, functional organisation, and food-web structure. New Zealand Journal of Marine and Freshwater Research, 38, 595-608.

Thompson, RM, Phillips, NR, \& Townsend, CR. (2009). Biological consequences of clear-cut logging around streams-moderating effects of management. Forest Ecology and Management, 257, 931-940.

Townsend, CR, Arbuckle, CJ, Crowl, TA, \& Scarsbrook, MR. (1997). The relationship between land use and physicochemistry, food resources and macro invertebrate communities in tributaries of the Taieri River, New Zealand: a hierarchically scaled approach. Freshwater Biology, 37, 177-191. 
van Dijk, AIJM, \& Keenan, RJ. (2007). Planted forests and water in perspective. Forest Ecology and Management, 251(1), 1-9.

Verburg, P, Hamill, K, Unwin, M, \& Abell, J. (2010). Lake water quality in New Zealand 2010: Status and trends (NIWA Client Report: HAM2010-107). Wellington, New Zealand: Ministry for the Environment.

Vörösmarty, CJ, Mclntyre, PB, Gessner, MO, Dudgeon, D, Prusevich, A, Green, P, Glidden, S, Bunn, SE, Sullivan, CA, Liermann, CR, \& Davies, PM. (2010). Global threats to human water security and river biodiversity. Nature, 467, 555-561.

Watt, MS, Wang, H, Rolando, CA, Zaayman, M, \& Martin, K. (2010). Adsorption of the herbicide terbuthylazine across a range of New Zealand forestry soils. Canadian Journal of Forest Research, 40, 1448-1457.

Webb, AA, Bonell, M, Bren, L, Lane, PNJ, McGuire, D, Neary, DG, Nettles, J, Scott, DF, Stednick, JD, \& Wang, Y (Eds.). (2012). Revisiting Experimental Catchment Studies in Forest Hydrology. Wallingford, Oxfordshire, UK: IAHS Publication.

Wilson, MA, \& Carpenter, SR. (1999). Economic valuation of freshwater ecosystem services in the United States: 1971-1997. Ecological Applications, 9(3), 772-783.

Winkworth, C. (2013). Antibiotic resistence genes in freshwater biofilms along a whole river. Journal of Water and Health, 11(2), 186-198. doi:10.2166/wh.2013.223.

Yao, RT, Barry, LE, Wakelin, SJ, Harrison, DR, Magnard, L-A, \& Payn, TW. (2013). Planted forests. In JR Dymond (Ed.), Ecosystem services in New Zealand: conditions and trends. Lincoln, New Zealand: Manaaki Whenua Press.

Young, RG, \& Huryn, AD. (1999). Effects of land use on stream metabolism and organic matter turnover. Ecological Applications, 9(4), 1359-1376.

Young, RG, Quarterman, AJ, Eyles, RF, Smith, RA, \& Bowden, WB. (2005). Water quality and thermal regime of the Motueka River: influences of land cover, geology and position in the catchment. New Zealand Journal of Marine and Freshwater Research, 39, 803-825.

\section{Submit your manuscript to a SpringerOpen ${ }^{\circ}$ journal and benefit from:}

- Convenient online submission

- Rigorous peer review

- Immediate publication on acceptance

- Open access: articles freely available online

- High visibility within the field

- Retaining the copyright to your article

Submit your next manuscript at $>$ springeropen.com 